Clemson University

TigerPrints

$1-2020$

The effect of health insurance on crime: Evidence from the Affordable Care Act Medicaid expansion

Qiwei He

Scott Barkowski

Follow this and additional works at: https://tigerprints.clemson.edu/economics_pubs

Part of the Health Economics Commons 


\title{
The Effect of Health Insurance on Crime: Evidence from the Affordable Care Act Medicaid Expansion*
}

\author{
Qiwei He $^{\dagger}$ Scott Barkowski ${ }^{\ddagger}$
}

October 2019

\begin{abstract}
Little evidence exists on the effect of the Affordable Care Act (ACA) on criminal behavior, a gap in the literature that this paper seeks to address. Using a simple model, we argue we should anticipate a decrease in time devoted to criminal activities in response to the expansion, since the availability of the ACA Medicaid coverage raises the opportunity cost of crime. This prediction is particularly relevant for the ACA expansion since it primarily affects childless adults, a population likely to contain individuals who engage in criminal behavior. We validate this forecast empirically using a difference-in-differences framework, estimating the expansion's effects on panel datasets of state- and county-level crime rates. Our estimates suggest that the ACA Medicaid expansion was negatively associated with burglary, vehicle theft, homicide, robbery, and assault. These crime-reduction spillover effects represent an important offset to the government's cost burden for the ACA Medicaid expansion.
\end{abstract}

Keywords: Health Insurance, Affordable Care Act (ACA) Medicaid Expansion, Criminal Behavior.

JEL Classification: I13, K14, K42.

Conflict of Interest Statement: The authors have no conflicts to disclose.

Running Title: The Effect of Health Insurance on Crime

${ }^{*}$ We thank Patrick Warren for helpful comments and Marisa Domino for her editorial guidance. All errors are our own.

†Qiwei He: Corresponding Author; The bulk of Dr. He's work on this project was performed while he was a doctoral student in the John E. Walker Department of Economics at Clemson University. His current affiliation is: Department of Global Health, China National Health Development Research Center, Wudongdalou, 9 Chegongzhuang Street, Xicheng District, Beijing, 100044, China. Email: heqw@ nhei.cn; phone: +86 13874804616.

${ }^{\ddagger}$ Scott Barkowski: John E. Walker Department of Economics, Clemson University, 240 Sirrine Hall, Clemson SC 29634, sbarkow@clemson.edu. 


\section{Introduction}

Among the most important governmental functions in the USA in recent decades has been improving population health and preventing crime. Both activities impose substantial costs on society. Recent estimates for the USA have put total annual health care spending at $\$ 3.5$ trillion (Martin et al. 2019) and the yearly cost of crime at $\$ 1.7$ trillion (Anderson, 2014) - a combined total representing more than a quarter of national output. When the federal government passed the Patient Protection and Affordable Care Act (ACA), one of its goals was to address the costs associated with health care, but in the process, it may have inadvertently addressed costs from crime, as well. One of the ACA's primary features was its Medicaid expansion, which targeted (among others) young, poor, childless adults, a group with low health insurance coverage rates historically (Broaddus, 2010) and one of the demographics most prone to crime (Farrington, 1986). In this article, we investigate the possibility that the expansion of Medicaid may have affected crime rates in the USA.

There are at least three reasons to expect that Medicaid health insurance could have an effect on criminal behavior. The first two derive from Medicaid's nature as a government transfer program. A large literature suggests that government transfer programs have been effective in reducing recidivism and crime (Mallar and Thornton, 1978; Berk et al., 1980; Berk and Rauma, 1983; Foley, 2011; Yang, 2017; Beach and Lopresti, 2019; Carr and Packham, 2019; Palmer et al., 2019; Tuttle, 2019). 11 These crime effects appear to be driven by the income transfer features of these programs, which do two related things: they make life outside of prison better, increasing the incentives to avoid crime which may result in prison; and they provide financial security, which decreases the need to resort to crime to make ends meet. Medicaid qualifies along both of these dimensions, since its availability when not incarcerated increases access and consumption of health care and even self-reported health, while also limiting financial exposure to medical bills and debt that might induce some individuals into criminal behavior (Finkelstein et al., 2012).

\footnotetext{
${ }^{1}$ In some cases, government programs have also been found unable to decrease crime, or, less often, to increase it (Jacob et al., 2015, Carr and Koppa, 2017, Costopoulos et al., 2017, Luallen et al., 2018).
} 
The third reason is that Medicaid increases access to treatment for those suffering from behavioral disorders or drug addiction. A large body of research has shown that substance abuse treatment is effective at reducing crime and recidivism (e.g., Marsch, 1998; Lurigio, 2000; Prendergast et al., 2002; Campbell et al., 2007; Mitchell et al., 2007; Deck et al., 2009; Bondurant et al., 2018), and while the literature on the effect of mental health treatment is less conclusive, it is suggestive of a small or moderate crime reduction (e.g., Cuellar et al., 2004; Evans Cuellar et al., 2006; Morrissey et al., 2007; Frank and McGuire, 2011; Constantine et al., 2012; Martin et al., 2012; Van Dorn et al., 2013; Morrissey et al., 2016). If Medicaid helps newly eligible individuals obtain treatment for mental health issues they would otherwise ignore (or treat less effectively), it could potentially induce a reduction in overall crime rates.

We formalize the notion that Medicaid could influence crime via a simple model that focuses on the government transfer program aspects of Medicaid. It predicts that Medicaid expansion would decrease the time allocated to illegal activities for eligible individuals under reasonable assumptions. We test this prediction empirically by performing a difference-in-differences (DID) analysis on both state- and county-level data for crime rates in the USA. Our findings indicate that the ACA Medicaid expansion reduced burglary by 3.8 percent, vehicle theft by 10.4 percent, homicide by 8.1 percent, robbery by 6.3 percent, and assault by 2.9 percent in expansion states. These findings are robust to a variety of alternative specifications. A back-of-the-envelope calculation indicates the value of this reduction in crime to expansion states is more than $\$ 10$ billion per year.

Two recent papers also study the effects of Medicaid expansions on crime, finding results consistent with ours. Wen et al. (2017) found the expansion of Medicaid via Health Insurance Flexibility and Accountability waivers during 2001-2008 reduced robbery, assault, and larceny. They attributed these effects to reduced substance abuse via increased treatment. Vogler (2017) also studies the ACA Medicaid expansion and uses an approach similar to our primary, statelevel analysis, finding crime-reduction effects similar to ours. Our work complements Wen et al. (2017) by studying an expansion that is much broader and by developing an incentives-focused theoretical model instead of one focused on a substance abuse mechanism. We differ from Vogler 
(2017) via our discussion of a theoretical model of health insurance and crime, longer data series, border-county-level analysis, and avoidance of endogenous police-spending control variables (Levitt, 2002) 2 Together, these papers and ours form a new literature that provides significant evidence for an effect of health insurance - specifically Medicaid - on crime.

\section{Background}

Medicaid is a federal and state partnership that provides free or low-cost health insurance coverage to a substantial number of lower-income Americans. Until the ACA, eligible individuals were primarily pregnant women, parents, the elderly, and the disabled. The ACA expanded eligibility to adults without children with household incomes at or below 138 percent of the federal poverty level. This included young adults that are most prone to criminal behavior. Originally intended to cover the entire country, the 2012 Supreme Court decision, National Federation of Independent Business v. Sebelius, gave states the option to participate in the ACA Medicaid expansion, resulting in a partial implementation across states. When the expansion took place on January 1, 2014, 24 states and Washington D.C. participated, and by January 2017, that number had risen to 31 plus Washington D.C. (see Table 1).

States that chose to expand saw large increases in Medicaid coverage rates. In 2014, the increase was about 11 percentage points while in 2015 it was approximately 16, an increase of roughly 50 percent (Wherry and Miller, 2016; Frean et al., 2017; Miller and Wherry, 2017). Among young adults, Medicaid coverage rates increased by about five percentage points in 2014 and nine in 2015 (Wehby and Lyu, 2018). For young adults with incomes under 138 percent of the poverty level, public coverage increased by about 11 percentage points (McMorrow et al., 2015). Furthermore, Medicaid coverage was also found to increase substantially for subpopulations of individuals with opioid or other substance abuse issues (Feder et al., 2017; Meinhofer and Witman,

\footnotetext{
${ }^{2}$ Vogler's work and ours were performed independently and concurrently. His draft was first publicly posted on SSRN when the first draft of this paper was being finalized. Despite the similarity of the main analyses of these papers, they also differ along essential dimensions. However, we obtain very similar results to his when we include police controls and use the same sample period as him (see Appendix Table 3 ).
} 
2018; Maclean and Saloner, 2019) as well as individuals with histories of involvement with the criminal justice system Winkelman et al. (2016) : ${ }^{3}$ and those with both history of justice system involvement and substance abuse disorders (Saloner et al., 2016).

Increases in coverage allow eligible individuals to have greater access to health care services, including for mental health and substance abuse treatments, as the vast majority of states' Medicaid programs cover such services (The Henry J. Kaiser Family Foundation, 2018). Surprisingly, though, the literature has found mixed results regarding whether the increases in Medicaid coverage for those with substance abuse problems resulted in additional substance addiction treatment (Saloner et al., 2016; Feder et al., 2017; Meinhofer and Witman, 2018; Maclean and Saloner, 2019). For this reason, when we discuss a theoretical framework for a relationship between crime and Medicaid in the next section, we focus on the government transfer rationale, rather than a medical treatment effect that presumably works through substance use disorder or mental health treatment mechanisms.

\section{The Theoretical Relationship Between Medicaid and Crimi- nal Behavior}

Modern theories of criminal behavior stretch across several disciplines, but two of the most prevalent come from the economic model of Becker (1968) and the self-control framework of Gottfredson and Hirschi (1990). Becker emphasized a utility-maximizing choice framework underlying decisions to engage in crime. Gottfredson and Hirschi acknowledged the role of cost-benefit determinations: $4^{4}$ but emphasized the role of individual differences in self-control (or lack thereof) that are stable over time. They note that low self-control helps explain phenomena that are difficult to

\footnotetext{
${ }^{3} \mathrm{~A}$ recent study by Winkelman et al. (2017) found previously-incarcerated young men experienced an increase in health insurance coverage in 2014 and 2015 that seemed to be driven by private coverage, not public. While this odd result raises some questions, one expects that private coverage would have similar effects on criminal behavior as those of Medicaid.

${ }^{4}$ In fact, the role of optimization is so strong that Gottfredson and Hirschi (1990) felt compelled to emphasize that "We do not believe that our theory is 'just another rehash of rational-choice theory" (p. 274).
} 
rationalize under utility-maximization frameworks. Examples include the fact that the propensity to commit crimes peaks in late teenage years and declines into adulthood and the seemingly low pecuniary gains of many crimes.

Despite these advantages of the self-control theory of crime, we develop a model in the strain of Becker's work for two reasons. First, our goal is not to develop a complete model of criminal behavior, which would involve notions of self-control, impulsiveness, and related characteristics, but merely to outline the theoretical role for Medicaid, which is only one of many determinants of crime. Second, the Medicaid expansion changed the environment in which eligible individuals make decisions. An optimization framework is ideal for modeling such circumstances, in contrast to theories involving stable individual characteristics, which do not change when the expansion occurs, and so are unlikely to be driving expansion responses.

We proceed by adapting the model of Ehrlich (1973), starting with an individual who is potentially eligible to receive Medicaid. He chooses how much time to devote to legitimate and criminal activities. After choosing, he is either imprisoned or not, with the likelihood of imprisonment depending on the chosen level of criminal activities. If not imprisoned, he receives utility from Medicaid coverage and from consuming his gains from legitimate and criminal activities. If he is imprisoned, he still consumes the gains from his activities, but does not receive utility from Medicaid, instead incurring a disutility penalty representing prison and any financial punishments. We note that while inmates can be enrolled in Medicaid while in prison in some states, federal policy prevents Medicaid from paying for any services except for hospital stays (Gates et al., 2014). Additionally, our model does not require that inmates receive no health care in prison (as prisons do provide some care), since the driver of behavior is not the lack of care, but an increased cost of criminal behavior which leads to missing out on the better life with Medicaid outside of prison.

Let $H_{l}$ and $H_{c}$ be the hours devoted to legal and criminal activities, respectively, and $T$ the total time available, so that $H_{l}+H_{c}=T$. We also define $w_{l}$ and $w_{c}$ as the wages for legal and criminal activities, which are assumed known by the individual, with $w_{l}<w_{c}$ since criminal activities entail higher risk. While we call these "wages", they do not have to be thought of as 
payments from jobs, but could represent benefits of other types, such as enjoyment from partaking in risky criminal activities or from non-monetary, legitimate behaviors like leisure. $P\left(H_{c}\right)$ is the probability of imprisonment, which increases with $H_{c}$, possibly at an increasing rate $\left(P^{\prime}(\cdot)>0\right.$ and $\left.P^{\prime \prime}(\cdot) \geq 0\right)$. The probability of not being imprisoned, then, is given by $1-P\left(H_{c}\right)$. Utility when not in prison is determined by $U_{N}=V\left(w_{l} H_{l}+w_{c} H_{c}\right)+M$, where $V(\cdot)$ represents a risk-averse utility function of income $\left(V^{\prime}(\cdot)>0\right.$ and $\left.V^{\prime \prime}(\cdot)<0\right)$, and $M>0$ is the individual's utility valuation of the difference between the benefits of Medicaid and prison health care. Medicaid benefits include the value of actual health care received, savings from not paying for alternative insurance, and financial protection from medical expenses. If the individual is arrested and imprisoned, his utility is $U_{A}=V\left(w_{l} H_{l}+w_{c} H_{c}\right)+J$, where $J<0$ represents prison disutility and any financial penalties.

Given these model features, the individual chooses $H_{l}$ and $H_{c}$ to maximize his expected utility, $E[u]:$

$$
\begin{gathered}
E[u]=\left[1-P\left(H_{c}\right)\right] U_{N}+P\left(H_{c}\right) U_{A}, \text { where } \\
U_{N}=V\left(w_{l} H_{l}+w_{c} H_{c}\right)+M ; \quad U_{A}=V\left(w_{l} H_{l}+w_{c} H_{c}\right)+J, \\
\text { s.t. } H_{l} \geqslant 0, H_{c} \geqslant 0, \text { and } H_{l}+H_{c}=T .
\end{gathered}
$$

Focusing on an interior solution: 5 substituting $H_{l}=T-H_{c}$ into $E[u]$, and rearranging we have

$$
E[u]=\left[1-P\left(H_{c}\right)\right]\left\{V\left[w_{l} T+\left(w_{c}-w_{l}\right) H_{c}\right]+M\right\}+P\left(H_{c}\right)\left\{V\left[w_{l} T+\left(w_{c}-w_{l}\right) H_{c}\right]+J\right\},
$$

where $H_{c}$ is the only choice variable. The derivative with respect to $H_{c}$ (after simplifying) is

$$
\frac{d E[u]}{d H_{c}}=P^{\prime}\left(H_{c}\right)(J-M)+V^{\prime}\left[w_{l} T+\left(w_{c}-w_{l}\right) H_{c}\right]\left(w_{c}-w_{l}\right)
$$

Setting this equal to zero and rearranging, we obtain

$$
V^{\prime}\left[w_{l} T+\left(w_{c}-w_{l}\right) H_{c}\right]\left(w_{c}-w_{l}\right)=P^{\prime}\left(H_{c}\right)(M-J),
$$

\footnotetext{
${ }^{5}$ By focusing on the interior solution we are essentially limiting our attention to individuals for whom criminal behavior is a realistic option (such as those with low self-control, in the terminology of Gottfredson and Hirschi) and excluding those who would be unlikely to commit any crime.
} 
the necessary (first-order) condition for optimality..$^{6}$

In equation (4), the left-hand side has the gain from substituting an hour of criminal activities for legitimate ones, $w_{c}-w_{l}$, weighted by the individual's marginal utility at the optimal criminality level, $V^{\prime}\left[w_{l} T+\left(w_{c}-w_{l}\right) H_{c}\right]$. On the right-hand side, the potential penalties of arrest, $M-J$ (the loss of Medicaid plus prison and fines), are weighted by the marginal increase in likelihood of being arrested from that additional hour of criminal behavior, $P^{\prime}\left(H_{c}\right)$. Thus, equation (4) shows that, at the optimal choice of $H_{c}$, the marginal gain from devoting one additional hour to crime (the left-hand side) equals the marginal cost from that additional hour (the right-hand side).

When Medicaid expands, the value of $M$ increases from zero to some positive value, increasing the value of the right-hand side of the equation (4). For the equation to stay balanced, $H_{c}$ must change. When $H_{c}$ decreases, $P^{\prime}\left(H_{c}\right)$ decreases, moving the right-hand side back towards equality, or stays constant (since $P^{\prime \prime}(\cdot) \geq 0$ ), while simultaneously $V^{\prime}\left[w_{l} T+\left(w_{c}-w_{l}\right) H_{c}\right]$ increases (since $\left.V^{\prime \prime}(\cdot)<0\right)$, thereby increasing the left-hand side until balance is restored..$^{7}$ The model, therefore, predicts that criminal behavior, and thereby actual crime rates, will fall in response to an expansion of Medicaid. As equation (4) shows, the mechanism driving this behavior is a rising opportunity cost to criminal activities. Prison forces individuals to miss out on the benefits of Medicaid, so they reduce activities that can lead to this result. Furthermore, since the model is predicated on the threat of going to jail, another prediction is that we should not expect to observe large effects for crimes where jail is unlikely. For example, larceny crimes are usually relatively minor with less severe punishments Rosenmerkel et al. (2009); Steffensmeier et al. (2015), implying effects on larceny should be weaker than for more serious crimes involving violence.

Finally, while our model provides useful predictions for our empirical analysis, our model is not a complete model of criminal behavior and has limitations. One is that Medicaid eligibility income thresholds are not modeled. For individuals near this threshold, the predictions of our

\footnotetext{
${ }^{6}$ The second-order condition requires $d^{2} E[u] / d H_{c}^{2}=P^{\prime \prime}\left(H_{c}\right)(J-M)+V^{\prime \prime}\left[w_{l} T+\left(w_{c}-w_{l}\right) H_{c}\right]\left(w_{c}-w_{l}\right)^{2}<0$, which is satisfied since we have assumed the individual is risk-averse $\left(V^{\prime \prime}(\cdot)<0\right)$ and the marginal rate of imprisonment is constant or increasing $\left(P^{\prime \prime}(\cdot) \geqslant 0\right)$.

${ }^{7}$ Note that because of the assumed shapes of $P$ and $V$, if $H_{c}$ were to increase, the sides in equation (4) would move further out of balance.
} 
model may not hold. For example, those just above the threshold may opt to pursue eligibility by substituting more criminal activities for legitimate work if it results in reported income falling below the threshold (presuming criminal income is not reported). Our model abstracts away from this: income plays no role. We argue the size of the expansion justifies this. Since thresholds increased from zero to 138 percent of the federal poverty level in most cases, few individuals gaining eligibility were in the neighborhood of the thresholds and experiencing these more subtle incentives. Another limitation is that our model ignores the possibility that crime prone individuals may move to states expanding Medicaid. This could potentially induce a spurious positive crime effect if the migration is substantial. However, recent research on Medicaid expansions (including the ACA) has found no evidence of migration effects between states, even for those living near state borders or with worse health (Schwartz and Sommers, 2014, Goodman, 2017). Nevertheless, these limitations of our model should be kept in mind by readers when reviewing our empirical analysis.

\section{Data}

The crime data used to create the dependent variables for our analysis come from the Federal Bureau of Investigation's (FBI) Uniform Crime Reports (UCR). State-level crime data for 2010-2016 are directly constructed by the FBI (U.S. Department of Justice, Federal Bureau of Investigation, 2011, 2012, 2013, 2014a, 2015, 2016, 2017a). Aggregated, county-level crime data for 2010-2014 and 2016 are obtained from the Inter-university Consortium for Political and Social Research (U.S. Department of Justice, Federal Bureau of Investigation, 2014b c d, 2017b c, 2019). The year 2015 is not included in our county-level sample since it has not yet been released to the public. The UCR collects data on eight major crime categories, but in our analysis we use only six of these. Arson offense rates were not released by the FBI during this time frame due to incomplete data collection, and we exclude rape since its reporting definition was revised by the FBI in 2013. The remaining categories are aggravated assault, criminal homicide, robbery, burglary, larceny-theft, 
and motor vehicle theft. The first three crime categories combined constitute the violent crime category, while the property crime category is a combination of the last three.

The crimes that form the basis of the UCR crime rate data are those reported to local police agencies, who report them to the FBI as part of monthly reports. This system has a major advantage in that it is not a random sample, but closer to a census of police agencies. The FBI reported that the law enforcement agencies active in the UCR program in 2013 represented 98 percent of the national population (U.S. Department of Justice, Federal Bureau of Investigation, 2014a). Nevertheless, there are several limitations to the UCR data. First, police agencies only report on crimes of which they are aware. Many crimes go unreported to law enforcement and so are missing from the UCR crime rates. Second, given that law enforcement agencies are in the business of preventing crime, there is an incentive for police agencies to under-report crime in an effort to give the appearance of effective policing. Third, Maltz (1999), Maltz and Targonski (2002), and Lynch and Jarvis (2008) point our that despite the large population covered by reporting agencies, those that do not report are not random, as they tend to be in areas with smaller populations. They note that this is particularly a problem of the county-level data.

We take steps to minimize this missing data issue in our analysis. First, our primary results are based on state-level data. While the non-reporting police agencies still influence state-level estimates, their impact is minimized since the larger population areas that tend to submit complete reports have much larger influence on these estimates.$^{8}$ Second, we weight our regressions by population, which, as the literature notes, should minimize this issue since it reduces the impact of smaller regions where the reporting problems are most prevalent (Lott and Whitley, 2003; Maltz and Targonski, 2003). Third, we drop all observations from our sample for any counties that have any missing data. ${ }^{9}$

Our primary independent variable of interest identifies state-years or county-years in which the ACA Medicaid expansion was adopted and in effect. This is based on detailed information

\footnotetext{
${ }_{8}$ Lynch and Jarvis (2008) found that more than 90 percent of agencies with populations above 10,000 reported all 12 months in 1992. For areas with 50,000 inhabitants, the share reporting each month was nearly 95 percent. In 2003, they found agencies with zero missing months covered almost 88 percent of the national population.

${ }^{9}$ There are no missing values for the state-level observations.
} 
on which states adopted the Medicaid expansion, and when, that was collected by the Kaiser Commission on Medicaid and the Uninsured and the Georgetown University Center for Children and Families via surveys of state Medicaid offices. The findings were released to the public through a series of reports published by the Henry J. Kaiser Family Foundation (Heberlein et al., 2011, 2012, 2013a b; Brooks et al., 2015, 2016, 2017). We supplemented these reports with the summary of the expansion produced by Kaestner et al. (2017).

Covariates measuring demographics and the economic environment are created using data from the American Community Survey (Ruggles et al., 2017). Demographic characteristics consist of age distribution and racial proportion of the population, including the share of young adults between the ages of 20 and 34 and the shares of white, black, native, and Asian individuals. Eco-

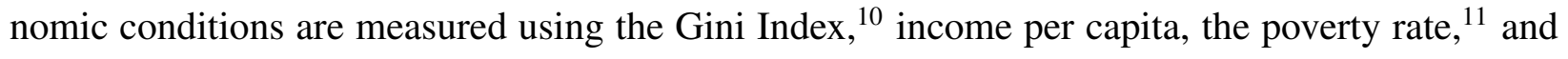
the unemployment rate. Additionally, we include contemporaneous and one year lags of state government spending in a few key areas to account for the government investment that may relate to crime and the Medicaid expansion. These are per capita spending on hospitals and health, public welfare, and education (U.S. Census Bureau, 2014a b c d, 2015, 2016, 2017, 2018).

We perform our analysis on two distinct samples: one including all states and Washington D.C. and one with all counties on expansion state borders. The county-level analysis is to account for geographic conditions that might affect crime, in the spirit of Dube et al. (2010). There are 1,184 of 3,233 total counties located along state boundaries in the USA mainland, and 567 of these 1,184 are located along a boundary between expansion and non-expansion states. Of these, we include 541 counties that have no missing crime rate data over the six year period of our sample.

Table 2 provides means and standard deviations of the dependent variable and covariates for the state sample. It shows the average crime rates in expansion states are smaller than those in non-expansion states in property crime categories but slightly larger in violent crime categories. However, the covariates are quite similar between the two groups. Summary statistics for the

\footnotetext{
${ }^{10}$ The Gini index is a measure of income inequality, which Ehrlich $(1973)$ argued served as a measure of the potential gains to crime.

${ }^{11}$ Poverty is measured as having a family income lower than the federal poverty level.
} 
border county sample are reported in Table 3. Most average crime rates in expansion states are slightly higher than in non-expansion states, but overall the differences in all variables are much smaller than in the state sample.

\section{Methodology}

We estimate the effect of Medicaid on crime rates by comparing changes in the natural logarithm of reported crime rates for expansion states to those of non-expansion states before and after the ACA Medicaid expansion. That is, we base our estimates on a DID model given by:

$$
\ln (\text { Crime rate })_{l t}=\beta_{1} \text { Medicaid }_{s t}+\mathbf{X}_{\mathbf{l t}} \lambda+\rho_{l}+\tau_{t}+u_{l t} .
$$

Here, $t$ indexes years while $l$ indexes the geographical level of the analysis, either state, $s$, or county, $c$. States' decisions about adopting the Medicaid expansion are expressed by a dummy variable, Medicaid $_{s t}$, which equals one if state $s$ adopted the Medicaid expansion in or before year $t$, and zero otherwise. In states that adopted the expansion after January 1st, 2014, we set Medicaid $_{s t}$ equal to one in the actual calendar year of the expansion if it occurs before July 1, but assign it in the following calendar year otherwise. In our analysis of county data, counties take the expansion assignments of their states. The dependent variable, $\ln (\text { Crime Rate })_{l t}$, represents the natural logarithm of the number of crimes committed per 100,000 residents. At the county level, some observations have zero values, so we add one to the crime rates before taking the logarithm 12 We represent a vector of state- or county-level demographic, economic, and government spending measures by $X_{l t},{ }^{13}$ while $\rho_{l}$ is a set of state or county fixed effects, $\tau_{t}$ a set of year fixed effects, and $u_{l t}$ the error term. We cluster the standard errors at the state-level to account for serial correlation (and correlation within states in our county-level analysis). As noted above, we use the state or

\footnotetext{
${ }^{12}$ Zeros are most prevalent for homicide, where more than half of county-year observations have zero values. Robbery has the next most frequent zeros, at more than a quarter of observations. Vehicle theft is third with greater than five percent zeros.

${ }^{13}$ Specific demographic, economic, and government spending controls are listed in the section above. Government spending variables always vary at the state level and enter equation 5] in logarithmic form.
} 
county populations as weights, which implies our estimates reflect the effect on the average person in the population and that more populous states or counties have greater influence on estimates.

We also estimate variations of equation (5) to examine the stability of our results. First, we produce estimates of the Medicaid effect for each year (omitting 2013 as the reference period). This "event study" specification allows us to examine the pre-trends in crime rates and how the effects of the expansion evolved over time (Autor, 2003; Kaestner et al., 2017). Second, we exclude five expansion states that implemented full expansions to both parents and childless adults prior to 2014, and three non-expansion states that had limited Medicaid expansions before 2014 (Kaestner et al. 2017). 14 Third, we limit our sample to only states that share borders with Medicaid expansion states. Forth, we re-estimate our models with additional time trend controls to remove crime trends unrelated to the Medicaid expansion and that are not captured by other variables. In one we include state-specific, linear time trends and in another treatment-specific, linear time trends. Fifth, we also run our main regression without year 2014 to investigate whether the crime reduction effect of the expansion was concentrated in that year. Sixth, to examine whether our results are concentrated in one state, we drop each state in turn from our data and re-estimate equation $(5)$ for the aggregated crime categories.

We also examine the robustness of our standard errors by calculating p-values using permutation methods (Ernst, 2004). To do so, we randomly assign 32 states to the Medicaid expansion 10,000 times, re-estimating equation (5) each time for each crime category. We then calculate p-values as the share of re-estimations that produce a Medicaid effect with an absolute value more extreme than the absolute value of our main result.

\footnotetext{
${ }^{14}$ The excluded states are Maine, Tennessee, and Wisconsin from the control group, and Delaware, Washington, D.C., Massachusetts, New York, and Vermont from the treatment group.
} 


\section{Results}

\subsection{Effects of the ACA Medicaid Expansion on Crime Rates}

Table 4 reports our main results for each of the eight crime-rate categories. Columns (1) and (2) present estimates for our state-level sample while columns (3) and (4) contain those based on the county-level sample. For each sample, we provide two versions of estimates for equation (5), one without controls for demographics and economic conditions, and one with - our preferred specification.

Overall, we find that that the ACA Medicaid expansion is associated with reductions in crime, a result that is consistent with our expectations based on our theoretical reasoning. All estimates take negative values, though not all are statistically significant at conventional levels. The effects are generally stronger for violent crimes than for property crimes, another result consistent with our expectations, since violent crimes tend to carry more severe punishments than property crimes. Moreover, our weakest results are consistently found for the larceny category, which carries the least severe punishments of the six sub-categories. Additionally, whether with or without controls, or using state- or county-level crime rates, we obtain estimates that are qualitatively similar.

For property crime, we obtain statistically significant estimates suggesting the expansion reduced burglary and motor vehicle theft, but not larceny-theft nor overall property crime (roughly two-thirds of which is comprised of larceny). Our preferred estimates in column (2) indicate that the burglary rate fell by 3.75 percent $(p<0.1)$ in expansion states relative to non-expansion states, corresponding to a decline of about 21.42 offenses per 100,000 inhabitants. 15 For motor vehicle theft, our estimates indicate a reduction of 10.4 percent $(p<0.05)$, or approximately 21.68 offenses per 100,000 in expansion states. Our estimates obtained using the contiguous-border counties are qualitatively and quantitatively similar to our state-level results.

For violent crime, our state-level estimates are significant and negative in each category when we include controls, and in three of four when we do not. For homicide, our preferred model

\footnotetext{
${ }^{15}$ Our calculations here for offenses in the burglary and motor vehicle theft categories use rates of 571.08 and 208.48 offenses per 100,000 inhabitants, respectively, for expansion states in 2013.
} 
(column 2) estimates a 8.13 percent reduction $(p<0.05)$, corresponding to 0.35 fewer homicides per 100,000 inhabitants 16 Robbery is reduced 6.33 percent $(p<0.05)$, or 6.82 robberies per 100,000, while we find assaults fell by 2.92 percent $(p<0.05)$, corresponding to 6.75 fewer per 100,000 in expansion states. Moreover, for aggregated violent crimes, we obtain a reduction of 4.43 percent $(p<0.01)$, implying almost 15.21 fewer violent offenses per 100,000 inhabitants in expansion states, which is mainly driven by the declines robberies and assaults.

In our contiguous-county sample in columns (3) and (4), we obtain similar results as from our state-level data for the robbery and overall violent crime categories. For homicide and assault, however, our estimates are not statistically significant even though the magnitudes of our estimates are similar. This would seem to be driven by the fact that the distributions of the county-level crime rates tend to exhibit more spread (as seen by comparison of standard deviations in Tables 2 and 3 ) than our state-level rates. Nevertheless, overall we find the effects for border counties are largely consistent with corresponding estimates generated using our state sample.

Appendix Figures 1 and 2 present visualizations of our estimates from column (2) of Table 4. Solid blue lines represent predicted crime rates for Medicaid expansion states, while the shortdashed, red lines represent the predicted counter-factual crime rates in expansion states in the absence of the expansion. The long-dashed, green lines represent predicted rates for non-expansion states. Both figures illustrate the declines in crime rates in expansion states after 2014, as implied by our estimates in Table 4 .

\subsection{Event Study Model}

In Figures 1 and 2 we present plots of coefficients from estimating our event study specification on our state-level sample (with Appendix Table 1 containing these results in tabular form). Here the coefficients represent the difference between crime rates in expansion states less those in nonexpansion states. Reviewing these estimates, we find evidence of similar trends between expansion

\footnotetext{
${ }^{16}$ In this paragraph, we base our offense calculations on crime rates for homicide, robbery, assault, and aggregated violent crime of $4.3,107.75,231.28$, and 343.33 offenses per 100,000 inhabitants, respectively, for expansion states in 2013.
} 
and non-expansion states during the period preceding the ACA expansion in 2014. None of our pre-2014 estimates are statistically significant individually, nor are they jointly, as Appendix Table 1 shows. This result is consistent with the parallel trends assumption underlying DID analyses. Additionally, the event study estimates also reveal that the expansion had significant crime reduction effects for all crime categories except larceny and aggravated assaults in 2014, but these effects diminished over 2015 and 2016. F-test p-values in Appendix Table 1 for joint tests of significance for post-treatment coefficients indicate they are jointly statistically significant for motor vehicle theft $(p<0.1)$, homicide $(p<0.05)$, and robbery $(p<0.01)$, as well as for the aggregated violent crime category $(p<0.05)$. However, there is only one coefficient across all categories that is significant during 2015 or 2016 on an individual basis (2015, vehicle theft, $p<0.1$ ). One potential explanation for this is that the expansion increased demand for health care, creating a shortage. This would degrade the value of Medicaid to eligible individuals, reducing incentives to cutting criminal behavior. While such a theory would be difficult to verify, there is some evidence that the expansion increased the likelihood that low-income individuals delayed care because of difficulty obtaining appointments for services (Miller and Wherry, 2017).

Figures 3 and 4 plot results from our event study model for contiguous-county crime rates (Appendix Table 2 reporting the numeric versions). The results from this sample are, again, largely consistent with the state-level data, but there is one notable difference. Here we do not find that the effects of the expansion diminish over time. In fact, for the overall categories of property and violent crime, our point estimates for 2016 are slightly larger than those in 2014. This is also true for four of six sub-categories. One could argue this is consistent with the possibility of a shortage caused by increased demand. Since border counties tend to be less-populous, shortages there may be less severe. However, we note that this is a possibility for which we are unable to provide evidence. 


\subsection{Robustness Checks}

Table 5 presents results for several robustness checks, all of which are based on our preferred specification which includes all controls. Column (1) reproduces our main results based on this preferred specification. In the first robustness check, reported in column (2), we drop several states that had implemented some version of expansions before 2014. Estimates are somewhat larger in magnitude for property crime categories and slightly smaller for violent ones when compared to our main results, but overall they are qualitatively similar. Column (3) contains results when limiting our sample to states sharing a border with an expansion state. Here we again find estimates that are similar to those of column (1), with the most notable difference being the insignificant burglary estimate, though it is larger in magnitude than that from column (1). Columns (4) and (5) report regression estimates from models including state-specific and treatment-specific, linear time-trends, respectively. In almost every case, the point estimates increase in magnitude as compared with our main results. In column (6), we present state-level estimates after excluding the year 2014. Here we find only one estimate, motor vehicle theft, is statistically significant at a conventional level $(p<0.1)$. Our estimates generally decrease in magnitude and also become much less precise,

though all estimates remain negative. These results formalize the observation from our event study results above that the effects in our state-level data were concentrated in 2014.

In the final column in Table 5, column (7), we report $p$-values produced by randomly assigning states to the Medicaid expansion and re-estimating our preferred specification 10,000 times. According to these $p$-values, our main estimates for vehicle theft, homicide, robbery, and the aggregated violent crimes category are significant at the five-percent level, while burglary is significant at ten-percent. These inference outcomes are substantially consistent with our significance results in column (1).

Finally, Appendix Figure 3 presents results from dropping each state in turn from our sample and re-estimating our DID model, equation (5). We performed this exercise for both aggregate crime categories. This figure shows that for property crime, four states' exclusions result in notable reductions in magnitude for our estimates. Nevertheless, our estimates for violent crime show little 
change when excluding these (or any other) states. Moreover, in every case (including the four mentioned) our estimates remain negative. Thus, this exercise suggests our results are not driven primarily by one state.

As a whole, the results presented in Table 5 and Appendix Figure 3 show that the estimates from our preferred regression persist across a range of robustness checks.

\section{Conclusion}

In this paper we discuss the theoretical and empirical evidence for a relationship between the ACA Medicaid expansion and crime in participating states. We argue theoretically that the expansion increases the opportunity cost of criminal behavior, thereby reducing crime rates when individuals substitute legitimate activities for criminal ones. We test this theory empirically using a differencein-differences research design and panel data on crime rates in the United States. We estimate statistically significant crime reductions in Medicaid expansion states in the categories of burglary, vehicle theft, homicide, robbery, and assault. Our estimate for larceny is also negative, but not statistically significant. These effects appear to diminish over time in estimates based on statelevel crime rates, but not in ones based on county-level data. Our results remain stable across a range of robustness checks.

To put these findings into context, we use our estimates to perform a back-of-the-envelope calculation of the annual welfare benefits of crime reduction to expansion states. We base this calculation on estimates produced by McCollister et al. (2010) of the total social cost per criminal act by category. These cost estimates include tangible costs to crime victims, the costs of the criminal justice system, the opportunity costs of criminals (who forgo gains from legitimate activities), as well as intangible costs to victims, such as pain and suffering. Based on these per offense estimates, in 2013, total welfare costs of crime in expansion states were about $\$ 8.2$ billion for burglary, $\$ 5.7$ billion for motor vehicle theft, $\$ 90.1$ billion for criminal homicide, $\$ 11.3$ billion for robbery, 
and $\$ 52.9$ billion for aggravated assault (all in 2019 dollars). ${ }^{17}$ As shown in Table 6 , we estimate that the Medicaid expansion reduced these welfare losses for adopting states by just under $\$ 10.5$ billion per year. This reduction is composed of $\$ 0.31$ billion in burglary, $\$ 0.59$ billion in vehicle theft, $\$ 7.33$ billion in homicide, $\$ 0.71$ billion in robbery, and $\$ 1.55$ billion in assault. 18 Given that Wolfe et al. (2017) estimated the total cost to the government of the ACA Medicaid expansion in 2017 to be $\$ 74.3$ billion (in 2019 dollars), our welfare calculation implies that the crime effect spillover offsets about one-seventh of the cost burden of the ACA Medicaid expansion.

Finally, in December 2018, a federal court ruled the ACA unconstitutional, including its Medicaid expansion. Currently, the law will remain in effect as challenges to the ruling make their way through the legal system, but the future of the ACA is uncertain: unless the ruling is overturned, the ACA will have to undergo changes to comply with the law. For policy makers considering possible adjustments, our results show that crime effects should be weighed during the process. If the expansion is not preserved, participating states could suffer an increase in local crime in addition to the loss of Medicaid coverage for lower income individuals. To limit the impact of this, states might consider augmenting other crime prevention policies if a Medicaid contraction occurs.

\footnotetext{
${ }^{17}$ These are calculated by multiplying the per criminal act welfare loss estimate from McCollister et al. (2010) for a category by the total number of offenses for that category in expansion states in 2013.

${ }^{18}$ For comparison, Wen et al. (2017) and Vogler (2017) both perform similar calculations, with the latter finding a $\$ 14.3$ billion welfare gain from the ACA-expansion crime reduction, and the former arguing that a Medicaid expansion that increases national substance abuse treatment spending by ten percent would lead to as much as a $\$ 6.0$ billion reduction in crime (both in 2019 dollars).
} 


\section{References}

Anderson, David A., The Cost of Crime, Hanover: Now Publishers, 2014.

Autor, David H., "Outsourcing at Will: The Contribution of Unjust Dismissal Doctrine to the Growth of Employment Outsourcing," Journal of labor economics, 2003, 21 (1), 1-42.

Beach, Brian and John Lopresti, “Losing by Less? Import Competition, Unemployment Insurance Generosity, and Crime: Losing by Less?,' Economic Inquiry, April 2019, 57 (2), 11631181.

Becker, Gary S, “Crime and Punishment: An Economic Approach,” Journal of Political Economy, 1968, 76 (2), 169-217.

Berk, Richard A. and David Rauma, "Capitalizing on Nonrandom Assignment to Treatments: A Regression-Discontinuity Evaluation of a Crime-Control Program," Journal of the American Statistical Association, 1983, 78 (381), 21-27.

_ , Kenneth J. Lenihan, and Peter H. Rossi, "Crime and Poverty: Some Experimental Evidence From Ex-Offenders," American Sociological Review, October 1980, 45 (5), 766.

Bondurant, Samuel R., Jason M. Lindo, and Isaac D. Swensen, "Substance Abuse Treatment Centers and Local Crime,” Journal of Urban Economics, March 2018, 104, 124-133.

Broaddus, Matthew, "Childless Adults Who Become Eligible for Medicaid in 2014 Should Receive Standard Benefits Package: Federal Government Will Assume Large Majority of Cost," Technical Report, Center on Budget and Policy Priorities, Washington, DC July 2010.

Brooks, Tricia, Joe Touschner, Samantha Artiga, Jessica Stephens, and Alexandra Gates, “Modern Era Medicaid: January 2015 Findings from a 50 State Survey of Eligibility, Enrollment, Renewal, and Cost-Sharing Policies in Medicaid and CHIP as of January 2015," Technical Report 8681, The Henry J. Kaiser Family Foundation, Menlo Park, CA January 2015. 
_, Karina Wagnerman, Samantha Artiga, Elizabeth Cornachione, and Petry Ubri, "Medicaid and CHIP Eligibility, Enrollment, Renewal, and Cost-Sharing Policies as of January 2017: Findings from a 50-State Survey,' Technical Report 8957, The Henry J. Kaiser Family Foundation, Menlo Park, CA January 2017.

_, Sean Miskell, Samantha Artiga, Elizabeth Cornachione, and Alexandra Gates, "Medicaid and CHIP Eligibility, Enrollment, Renewal, and Cost-Sharing Policies as of January 2016: Findings from a 50-State Survey," Technical Report 8824, The Henry J. Kaiser Family Foundation, Menlo Park, CA January 2016.

Campbell, Kevin M, Dennis Deck, and Antoinette Krupski, "Impact of Substance Abuse Treatment on Arrests among Opiate Users in Washington State," American Journal on Addictions, January $2007,16(6), 510-520$.

Carr, Jillian and Vijetha Koppa, "Housing Vouchers, Income Shocks, and Crime: Evidence from a Lottery," SSRN Electronic Journal, July 2017.

Carr, Jillian B. and Analisa Packham, "SNAP Benefits and Crime: Evidence from Changing Disbursement Schedules," The Review of Economics and Statistics, May 2019, 101 (2), 310325.

Constantine, Robert J., John Robst, Ross Andel, and Gregory Teague, “The Impact of Mental Health Services on Arrests of Offenders with a Serious Mental Illness.," Law and Human Behavior, June 2012, 36 (3), 170-176.

Costopoulos, Julie S., Amy M. Plewinski, Patricia L. Monaghan, and Vanessa A. Edkins, "The Impact of Us Government Assistance on Recidivism," Criminal Behaviour and Mental Health, October 2017, 27 (4), 303-311.

Cuellar, Alison Evans, Larkin S. McReynolds, and Gail A. Wasserman, "A Cure for Crime: Can Mental Health Treatment Diversion Reduce Crime Among Youth?," Journal of Policy Analysis and Management, 2006, 25 (1), 197-214. 
Cuellar, Alison Evans, Sara Markowitz, and Anne M Libby, "Mental Health and Substance Abuse Treatment and Juvenile Crime," The Journal of Mental Health Policy and Economics, June 2004, 7 (2), 59-68.

Deck, Dennis, Wyndy Wiitala, Bentson McFarland, Kevin Campbell, John Mullooly, Antoinette Krupski, and Dennis McCarty, "Medicaid Coverage, Methadone Maintenance, and Felony Arrests: Outcomes of Opiate Treatment in Two States," Journal of Addictive Diseases, 2009, $28(2), 89-102$.

Dorn, Richard A. Van, Sarah L. Desmarais, John Petrila, Diane Haynes, and Jay P. Singh, "Effects of Outpatient Treatment on Risk of Arrest of Adults With Serious Mental Illness and Associated Costs," Psychiatric Services, September 2013, 64 (9), 856-862.

Dube, Arindrajit, T William Lester, and Michael Reich, "Minimum Wage Effects across State Borders: Estimates Using Contiguous Counties," The review of economics and statistics, 2010, $92(4), 945-964$.

Ehrlich, Isaac, "Participation in Illegitimate Activities: A Theoretical and Empirical Investigation,” Journal of Political Economy, May 1973, 81 (3), 521-565.

Ernst, Michael D., "Permutation Methods: A Basis for Exact Inference," Statistical Science, November 2004, 19 (4), 676-685.

Farrington, David P., “Age and Crime,” Crime and Justice, January 1986, 7, 189-250.

Feder, Kenneth A., Ramin Mojtabai, Noa Krawczyk, Andrea S. Young, Marc Kealhofer, Kayla N. Tormohlen, and Rosa M. Crum, "Trends in Insurance Coverage and Treatment Among Persons with Opioid Use Disorders Following the Affordable Care Act," Drug and Alcohol Dependence, October 2017, 179, 271-274.

Finkelstein, Amy, Sarah Taubman, Bill Wright, Mira Bernstein, Jonathan Gruber, Joseph P. Newhouse, Heidi Allen, Katherine Baicker, and Oregon Health Study Group, “The Ore- 
gon Health Insurance Experiment: Evidence from the First Year*," The Quarterly Journal of Economics, August 2012, 127 (3), 1057-1106.

Foley, C Fritz, "Welfare Payments and Crime," The Review of Economics and Statistics, February 2011, 93 (1), 97-112.

Frank, Richard G. and Thomas G. McGuire, "Mental Health Treatment and Criminal Justice Outcomes," in Philip J. Cook, Jens Ludwig, and Justin McCrary, eds., Controlling Crime: Strategies and Tradeoffs, University of Chicago Press, September 2011, pp. 167 - 207.

Frean, Molly, Jonathan Gruber, and Benjamin D. Sommers, "Premium Subsidies, the Mandate, and Medicaid Expansion: Coverage Effects of the Affordable Care Act," Journal of Health Economics, May 2017, 53, 72-86.

Gates, Alexandra, Samantha Artiga, and Robin Rudowitz, "Health Coverage and Care for the Adult Criminal Justice-Involved Population,” Issue Brief, The Henry J. Kaiser Family Foundation, Menlo Park, CA September 2014.

Goodman, Lucas, "The Effect of the Affordable Care Act Medicaid Expansion on Migration: Effect of the ACA Medicaid Expansion on Migration," Journal of Policy Analysis and Management, January 2017, 36 (1), 211-238.

Gottfredson, Michael R. and Travis Hirschi, A General Theory of Crime, Stanford, CA: Stanford University Press, 1990.

Heberlein, Martha, Tricia Brooks, Joan Alker, Samantha Artiga, and Jessica Stephens, "Getting into Gear for 2014: Findings from a 50-State Survey of Eligibility, Enrollment, Renewal, and Cost-Sharing Policies in Medicaid and CHIP, 2012-2013,” Technical Report, The Henry J. Kaiser Family Foundation, Washington, DC January 2013.

_, _, Jocelyn Guyer, Samantha Artiga, and Jessica Stephens, "Holding Steady, Looking Ahead: Annual Findings of a 50-State Survey of Eligibility Rules, Enrollment and Renewal 
Procedures, and Cost Sharing Practices in Medicaid and CHIP, 2010-2011," Technical Report, The Henry J. Kaiser Family Foundation, Washington, DC January 2011.

${ }_{-},,_{-},,_{-}$, and $\ldots$, "Performing Under Pressure: Annual Findings of a 50-State Survey of Eligibility, Enrollment, Renewal, and Cost-Sharing Policies in Medicaid and CHIP, 2011-2012,"

Technical Report, The Henry J. Kaiser Family Foundation, Washington, DC January 2012.

_, _, Samantha Artiga, and Jessica Stephens, "Getting into Gear for 2014: Shifting New Medicaid Eligibility and Enrollment Policies Into Drive,’ Technical Report, The Henry J. Kaiser Family Foundation, Washington, DC November 2013.

Jacob, Brian A., Max Kapustin, and Jens Ludwig, "The Impact of Housing Assistance on Child Outcomes: Evidence from a Randomized Housing Lottery," The Quarterly Journal of Economics, February 2015, 130 (1), 465-506.

Kaestner, Robert, Bowen Garrett, Jiajia Chen, Anuj Gangopadhyaya, and Caitlyn Fleming, "Effects of ACA Medicaid Expansions on Health Insurance Coverage and Labor Supply," Journal of Policy Analysis and Management, 2017, 36 (3), 608-642.

Levitt, Steven D, "Using Electoral Cycles in Police Hiring to Estimate the Effects of Police on Crime: Reply," The American Economic Review, 2002, 92 (4), 1244-1250.

Lott, John R and John Whitley, "Measurement Error in County-Level UCR Data," Journal of Quantitative Criminology, June 2003, 19 (2), 185-198.

Luallen, Jeremy, Jared Edgerton, and Deirdre Rabideau, "A Quasi-Experimental Evaluation of the Impact of Public Assistance on Prisoner Recidivism," Journal of Quantitative Criminology, September 2018, 34 (3), 741-773.

Lurigio, Arthur J., "Drug Treatment Availability and Effectiveness: Studies of the General and Criminal Justice Populations," Criminal Justice and Behavior, 2000, 27 (4), 495-528. 
Lynch, James P. and John P. Jarvis, "Missing Data and Imputation in the Uniform Crime Reports and the Effects on National Estimates," Journal of Contemporary Criminal Justice, February 2008, 24 (1), 69-85.

Maclean, Johanna Catherine and Brendan Saloner, "The Effect of Public Insurance Expansions on Substance Use Disorder Treatment: Evidence from the Affordable Care Act," Journal of Policy Analysis and Management, March 2019, 38 (2), 366-393.

Mallar, Charles D. and Craig V. D. Thornton, "Transitional Aid for Released Prisoners: Evidence from the Life Experiment," The Journal of Human Resources, 1978, 13 (2), 208.

Maltz, Michael D, "Bridging Gaps in Police Crime Data," Technical Report NCJ 176365, U.S. Department of Justice, Bureau of Justice Statistics, Washington, D.C. September 1999.

_ and Joseph Targonski, "A Note on the Use of County-Level UCR Data," Journal of Quantitative Criminology, September 2002, 18 (3), 297-318.

_ and _, "Measurement and Other Errors in County-Level UCR Data: A Reply to Lott and Whitley," Journal of Quantitative Criminology, June 2003, 19 (2), 199-206.

Marsch, Lisa A., "The Efficacy of Methadone Maintenance Interventions in Reducing Illicit Opiate Use, HIV Risk Behavior and Criminality: A Meta-Analysis: (Alcoholism and Drug Addiction)," Addiction, April 1998, 93 (4), 515-32. Copyright - Copyright Carfax Publishing Company Apr 1998; Last updated - 2017-10-27; CODEN - ADICE5.

\section{Martin, Anne B., Micah Hartman, Benjamin Washington, Aaron Catlin, and National Health} Expenditure Accounts Team, "National Health Care Spending In 2017: Growth Slows To Post-Great Recession Rates; Share Of GDP Stabilizes," Health Affairs, January 2019, 38 (1), $10.1377 /$ hlthaff.

Martin, Michael S., Shannon K. Dorken, Ashley D. Wamboldt, and Sarah E. Wootten, “Stopping the Revolving Door: A Meta-Analysis on the Effectiveness of Interventions for Criminally 
Involved Individuals With Major Mental Disorders," Law and Human Behavior, 2012, 36 (1), 1-12.

McCollister, Kathryn E, Michael T French, and Hai Fang, "The Cost of Crime to Society: New Crime-Specific Estimates for Policy and Program Evaluation,” Drug and alcohol dependence, 2010, 108 (1), 98-109.

McMorrow, Stacey, Genevieve M. Kenney, Sharon K. Long, and Nathaniel Anderson, "Uninsurance Among Young Adults Continues To Decline, Particularly In Medicaid Expansion States," Health Affairs, April 2015, 34 (4), 616-620.

Meinhofer, Angélica and Allison E. Witman, "The Role of Health Insurance on Treatment for Opioid Use Disorders: Evidence from the Affordable Care Act Medicaid Expansion,' Journal of Health Economics, July 2018, 60, 177-197.

Miller, Sarah and Laura R. Wherry, "Health and Access to Care during the First 2 Years of the ACA Medicaid Expansions," New England Journal of Medicine, March 2017, 376 (10), 947-956.

Mitchell, Ojmarrh, David B. Wilson, and Doris L. MacKenzie, "Does Incarceration-Based Drug Treatment Reduce Recidivism? A Meta-Analytic Synthesis of the Research," Journal of Experimental Criminology, December 2007, 3 (4), 353-375.

Morrissey, Joseph P, Gary S Cuddeback, Alison Evans Cuellar, and Henry J Steadman, “The Role of Medicaid Enrollment and Outpatient Service Use in Jail Recidivism among Persons with Severe Mental Illness,” Psychiatric Services, June 2007, 58 (6), 794-801.

Morrissey, Joseph P., Marisa E. Domino, and Gary S. Cuddeback, "Expedited Medicaid Enrollment, Mental Health Service Use, and Criminal Recidivism Among Released Prisoners With Severe Mental Illness," Psychiatric Services, August 2016, 67 (8), 842-849. 
Palmer, Caroline, David C. Phillips, and James X. Sullivan, "Does Emergency Financial Assistance Reduce Crime?," Journal of Public Economics, January 2019, 169, 34-51.

Prendergast, Michael L, Deborah Podus, Eunice Chang, and Darren Urada, "The Effectiveness of Drug Abuse Treatment: A Meta-Analysis of Comparison Group Studies," Drug and Alcohol Dependence, June 2002, 67 (1), 53-72.

Rosenmerkel, Sean, Matthew Durose, and Donald Farole Jr., "Felony Sentences in State Courts, 2006 - Statistical Tables,” Technical Report NCJ 226846, U.S. Department of Justice, Bureau of Justice Statistics December 2009.

Ruggles, Steven, Katie Genadek, Ronald Goeken, Josiah Grover, and Matthew Sobek, "Integrated Public Use Microdata Series, American Community Survey: Version 5.0.," Technical Report, University of Minnesota, Minneapolis 2017.

Saloner, Brendan, Sachini N. Bandara, Emma E. McGinty, and Colleen L. Barry, "JusticeInvolved Adults With Substance Use Disorders: Coverage Increased But Rates Of Treatment Did Not In 2014," Health Affairs, June 2016, 35 (6), 1058-1066.

Schwartz, Aaron L. and Benjamin D. Sommers, "Moving For Medicaid? Recent Eligibility Expansions Did Not Induce Migration From Other States," Health Affairs, January 2014, 33 (1), $88-94$.

Steffensmeier, Darrell, Casey T. Harris, and Noah Painter-Davis, "Gender and Arrests for Larceny, Fraud, Forgery, and Embezzlement: Conventional or Occupational Property Crime Offenders?," Journal of Criminal Justice, May 2015, 43 (3), 205-217.

The Henry J. Kaiser Family Foundation, "National Summary of Medicaid Behavioral Health Services Database,” Technical Report July 2018.

Tuttle, Cody, "Snapping Back: Food Stamp Bans and Criminal Recidivism," American Economic Journal: Economic Policy, May 2019, 11 (2), 301-327. 
U.S. Census Bureau, “Annual Survey of State and Local Government Finances, 2009,” December 2014.

_. , “Annual Survey of State and Local Government Finances, 2010,” December 2014.

_ , “Annual Survey of State and Local Government Finances, 2011,” December 2014.

_. , “Annual Survey of State and Local Government Finances, 2012,” December 2014.

_, "Annual Survey of State and Local Government Finances, 2013,” September 2015.

_ , “Annual Survey of State and Local Government Finances, 2014,” December 2016.

_, " “Annual Survey of State and Local Government Finances, 2015,” September 2017.

_ , “Annual Survey of State and Local Government Finances, 2016,” September 2018.

U.S. Department of Justice, Federal Bureau of Investigation, "Crime in the United States, 2010," September 2011.

_ , “Crime in the United States, 2011,” September 2012.

_ , "Crime in the United States, 2012," October 2013.

_, "Crime in the United States, 2013," November 2014.

_, "Uniform Crime Reporting Program Data: County-Level Detailed Arrest and Offense Data, United States, 2010,” June 2014.

_, "Uniform Crime Reporting Program Data: County-Level Detailed Arrest and Offense Data, United States, 2011,” June 2014.

_, "Uniform Crime Reporting Program Data: County-Level Detailed Arrest and Offense Data, United States, 2012," June 2014.

_ , "Crime in the United States, 2014," September 2015. 
_ , "Crime in the United States, 2015," September 2016.

_ , "Crime in the United States, 2016," September 2017.

_., "Uniform Crime Reporting Program Data: County-Level Detailed Arrest and Offense Data, United States, 2013," September 2017.

_, "Uniform Crime Reporting Program Data: County-Level Detailed Arrest and Offense Data, United States, 2014,” September 2017.

_ , "Uniform Crime Reporting Program Data: County-Level Detailed Arrest and Offense Data, United States, 2016," January 2019.

Vogler, Jacob, "Access to Health Care and Criminal Behavior: Short-Run Evidence from the ACA Medicaid Expansions," November 2017. SSRN Working Paper: https://papers.ssrn.com/sol3/papers.cfm?abstract_id=3042267.

Wehby, George L. and Wei Lyu, "The Impact of the ACA Medicaid Expansions on Health Insurance Coverage through 2015 and Coverage Disparities by Age, Race/Ethnicity, and Gender," Health Services Research, April 2018, 53 (2), 1248-1271.

Wen, Hefei, Jason M. Hockenberry, and Janet R. Cummings, “The Effect of Medicaid Expansion on Crime Reduction: Evidence from HIFA-Waiver Expansions," Journal of Public Economics, October 2017, 154, 67-94.

Wherry, Laura R. and Sarah Miller, "Early Coverage, Access, Utilization, and Health Effects Associated With the Affordable Care Act Medicaid Expansions: A Quasi-Experimental Study," Annals of Internal Medicine, June 2016, 164 (12), 795.

Winkelman, Tyler N. A., Edith C. Kieffer, Susan D. Goold, Jeffrey D. Morenoff, Kristen Cross, and John Z. Ayanian, "Health Insurance Trends and Access to Behavioral Healthcare Among Justice-Involved Individuals—United States, 2008-2014,' Journal of General Internal Medicine, December 2016, 31 (12), 1523-1529. 
_ , HwaJung Choi, and Matthew M. Davis, “The Affordable Care Act, Insurance Coverage, and Health Care Utilization of Previously Incarcerated Young Men: 2008-2015,’ American Journal of Public Health, May 2017, 107 (5), 807-811.

Wolfe, Christian J, Kathryn E Rennie, and Christopher J Truffer, “2017 Actuarial Report on the Financial Outlook for Medicaid," Technical Report, U.S. Department of Health and Human Services, Centers for Medicare \& Medicaid Services, Office of the Actuary 2017.

Yang, Crystal S., "Does Public Assistance Reduce Recidivism?," American Economic Review, May 2017, 107 (5), 551-555. 
Table 1: Summary of ACA Medicaid Expansion Adoption as of January 2017

Control Group (No Expansion After 2014)

\begin{tabular}{cc}
\hline No Prior Expansion & $\begin{array}{c}\text { Prior Limited Expansions for } \\
\text { Parents and/or Childless Adults }\end{array}$ \\
\hline Alabama & Maine \\
Florida & Tennessee \\
Georgia & Wisconsin \\
Idaho & \\
Kansas & \\
Mississippi & \\
Missouri & \\
Nebraska & \\
North Carolina & \\
Oklahoma & \\
South Carolina & \\
South Dakota & \\
Texas & \\
Utah & \\
Virginia & \\
Wyoming & \\
\hline
\end{tabular}

Treatment Group (Expansion on Jan. 1, 2014 or Later)

\begin{tabular}{ccc}
\hline No Prior Expansion & $\begin{array}{c}\text { Prior Limited Expansions for } \\
\text { Parents and/or Childless Adults }\end{array}$ & $\begin{array}{c}\text { Prior Full Expansions for } \\
\text { Parents and Childless Adults }\end{array}$ \\
\hline Alaska $^{1}$ & Arizona & Delaware \\
Arkansas & California & Washington, D.C. \\
Kentucky & Connecticut & Massachusetts \\
Louisiana $^{1}$ & Colorado & New York \\
Michigan $^{1}$ & Hawaii & Vermont \\
Montana $^{1}$ & Illinois & \\
Nevada $_{\text {New Hampshire }}{ }^{1}$ & Indiana & \\
New Mexico & Iowa & \\
North Dakota & Maryland & \\
Ohio & Minnesota & \\
Pennsylvania & & \\
West Virginia & New Jersey & \\
& Oregon & \\
\hline Notes: Expansions taking place & after January 1, 2014 include: & Michigan (4/1/2014), New \\
Hampshire (8/15/2014), Pennsylvania (1/1/2015), Indiana (2/1/2015), Alaska (9/1/2015), Montana \\
(1/1/2016), and Louisiana (7/1/2016). Presentation format adopted from Kaestner et al. (2017)
\end{tabular}


Table 2: Summary Statistics: All States Sample 2010-2016

\begin{tabular}{|c|c|c|c|}
\hline & All States & Expansion States & Non-Expansion States \\
\hline & Mean (S.D.) & Mean (S.D.) & Mean (S.D.) \\
\hline \multicolumn{4}{|l|}{ Dependent Variables: } \\
\hline \multicolumn{4}{|c|}{ Crime Rate (per 100,000 residents) } \\
\hline Property Crime & 2,713.37 (662.09) & $2,666.87(701.24)$ & $2,791.69(584.51)$ \\
\hline Burglary & $580.32(214.14)$ & $555.44(197.87)$ & $622.22(233.89)$ \\
\hline Larceny Theft & $1,922.97(451.25)$ & $1,891.58(503.07)$ & $1,975.82(342.26)$ \\
\hline Motor Vehicle Theft & $210.08(104.20)$ & $219.85(119.02)$ & $193.64(70.13)$ \\
\hline Violent Crime & $338.59(176.32)$ & $353.71(197.97)$ & $313.13(128.83)$ \\
\hline Criminal Homicide & $4.59(2.89)$ & $4.62(3.33)$ & $4.54(1.94)$ \\
\hline Robbery & $94.42(84.91)$ & $106.96(101.34)$ & $73.32(37.13)$ \\
\hline Aggravated Assault & $239.58(110.36)$ & $242.14(115.61)$ & $235.27(101.17)$ \\
\hline \multicolumn{4}{|l|}{ Control Variables: } \\
\hline \multicolumn{4}{|c|}{ State Demographics \& Economics } \\
\hline Per Capita Income $(\$ 1,000 s)$ & $28.40(4.80)$ & $29.80(5.19)$ & $26.05(2.79)$ \\
\hline Percentage Gini Index & $45.80(2.19)$ & $45.94(2.34)$ & $45.57(1.91)$ \\
\hline Percent Age 20-34 & $20.42(1.95)$ & $20.50(2.25)$ & $20.30(1.30)$ \\
\hline Percent White & $76.95(13.57)$ & $76.02(15.01)$ & $78.52(10.60)$ \\
\hline Percent Black & $11.14(10.90)$ & $10.01(10.59)$ & $13.05(11.18)$ \\
\hline Percent Native & $1.58(2.79)$ & $1.64(3.05)$ & $1.48(2.28)$ \\
\hline Percent Asian & $3.82(5.49)$ & $4.85(6.66)$ & $2.09(1.20)$ \\
\hline Poverty Rate & $14.27(3.13)$ & $13.81(3.20)$ & $15.03(2.87)$ \\
\hline Unemployment Rate & $6.65(2.11)$ & $6.83(2.12)$ & $6.35(2.07)$ \\
\hline \multicolumn{4}{|c|}{ State Government Expenditures (\$ per capita) } \\
\hline Healthcare & $2,160.15(656.02)$ & $2,233.89(716.34)$ & $2,035.96(518.65)$ \\
\hline Welfare & $762.69(387.84)$ & $884.83(422.53)$ & $556.98(190.06)$ \\
\hline Education & $2,963.99(610.55)$ & $3,102.31(579.25)$ & 2,731.02 (592.75) \\
\hline Observations (States $\times$ Years) & $51 \times 7=357$ & $32 \times 7=224$ & $19 \times 7=133$ \\
\hline
\end{tabular}


Table 3: Summary Statistics: Contiguous-Border Counties Sample 2010-2014, 2016

\begin{tabular}{|c|c|c|c|}
\hline & All Border Counties & Expansion Counties & Non-Expansion Counties \\
\hline & Mean (S.D.) & Mean (S.D.) & Mean (S.D.) \\
\hline \multicolumn{4}{|l|}{ Dependent Variables: } \\
\hline \multicolumn{4}{|l|}{ Crime Rate (per 100,000 residents) } \\
\hline Property Crime & $1,850.92(1,180.02)$ & $1,858.03(1,143.97)$ & $1,838.80(1,239.47)$ \\
\hline Burglary & $453.07(341.80)$ & $464.41(339.83)$ & $433.72(344.41)$ \\
\hline Larceny Theft & $1,297.43(854.47)$ & $1,296.32(813.50)$ & $1,299.31(920.47)$ \\
\hline Motor Vehicle Theft & $100.43(108.10)$ & $97.30(102.46)$ & $105.77(116.93)$ \\
\hline Violent Crime & $199.03(213.33)$ & $199.30(202.24)$ & $198.57(231.10)$ \\
\hline Criminal Homicide & $2.96(6.05)$ & $2.92(5.61)$ & $3.02(6.74)$ \\
\hline Robbery & $31.24(61.91)$ & $35.21(63.18)$ & $24.47(59.10)$ \\
\hline Aggravated Assault & $164.83(173.96)$ & $161.17(162.23)$ & $171.08(192.23)$ \\
\hline \multicolumn{4}{|l|}{ Control Variables: } \\
\hline \multicolumn{4}{|l|}{ State Demographics \& Economics } \\
\hline Per Capita Income $(\$ 1,000 s)$ & $23.96(6.05)$ & $24.14(5.70)$ & $23.65(6.59)$ \\
\hline Percentage Gini Index & $43.12(3.43)$ & $43.37(3.28)$ & $42.69(3.64)$ \\
\hline Percent Age 20-34 & $17.61(3.87)$ & $17.57(3.45)$ & $17.68(4.50)$ \\
\hline Percent White & $87.41(14.28)$ & $87.35(14.62)$ & $87.52(13.66)$ \\
\hline Percent Black & $6.10(11.49)$ & $6.66(11.87)$ & $5.15(10.74)$ \\
\hline Percent Native & $1.88(7.43)$ & $1.60(7.48)$ & $2.34(7.33)$ \\
\hline Percent Asian & $1.01(1.67)$ & $1.03(1.48)$ & $0.96(1.96)$ \\
\hline Poverty Rate & $15.47(6.53)$ & $15.48(6.39)$ & $15.45(6.77)$ \\
\hline Unemployment Rate & $7.81(3.31)$ & $8.20(3.18)$ & $7.15(3.42)$ \\
\hline \multicolumn{4}{|c|}{ State Government Expenditures (\$ per capita) } \\
\hline Healthcare & $1,991.55(481.01)$ & $2,078.51(511.20)$ & $1,839.21(368.97)$ \\
\hline Welfare & $695.12(256.15)$ & $757.94(268.70)$ & $588.01(190.30)$ \\
\hline Education & $2,833.56(441.85)$ & 2,927.21 (336.49) & $2673.88(542.93)$ \\
\hline Observations (Counties $\times$ Years) & $541 \times 6=3,246$ & $341 \times 6=2,046$ & $200 \times 6=1,200$ \\
\hline
\end{tabular}


Table 4: Medicaid Expansion Effect on Crime Rates: DID Result

\begin{tabular}{|c|c|c|c|c|}
\hline \multirow{2}{*}{ DID Estimates } & \multicolumn{2}{|c|}{ All States Sample } & \multicolumn{2}{|c|}{ Contiguous-Border Counties Sample } \\
\hline & $(1)$ & $(2)$ & (3) & (4) \\
\hline \multicolumn{5}{|l|}{ Dependent Variables: } \\
\hline \multicolumn{5}{|c|}{ Natural Log of Crime Rate per 100,000 residents } \\
\hline \multirow[t]{2}{*}{ Property Crime } & -0.0191 & -0.0256 & -0.0274 & -0.0255 \\
\hline & $(0.020)$ & $(0.021)$ & $(0.020)$ & $(0.017)$ \\
\hline \multirow[t]{2}{*}{ Burglary } & $-0.0376^{*}$ & $-0.0375^{*}$ & $-0.0513^{*}$ & $-0.0455^{*}$ \\
\hline & $(0.022)$ & $(0.022)$ & $(0.031)$ & $(0.026)$ \\
\hline \multirow[t]{2}{*}{ Larceny Theft } & -0.0045 & -0.0135 & -0.0043 & -0.00715 \\
\hline & $(0.019)$ & $(0.019)$ & $(0.019)$ & $(0.017)$ \\
\hline \multirow[t]{2}{*}{ Motor Vehicle Theft } & $-0.121 * * *$ & $-0.104 * *$ & $-0.112 * *$ & $-0.0951 * *$ \\
\hline & $(0.039)$ & $(0.045)$ & $(0.045)$ & $(0.038)$ \\
\hline \multirow[t]{2}{*}{ Violent Crime } & $-0.0485^{* * *}$ & $-0.0443 * * *$ & $-0.0551 * *$ & $-0.0527 * *$ \\
\hline & $(0.016)$ & $(0.014)$ & $(0.027)$ & $(0.024)$ \\
\hline \multirow[t]{2}{*}{ Criminal Homicide } & $-0.112 * * *$ & $-0.0813 * *$ & -0.0740 & -0.0609 \\
\hline & $(0.036)$ & $(0.032)$ & $(0.040)$ & $(0.042)$ \\
\hline \multirow[t]{2}{*}{ Robbery } & $-0.0886 * * *$ & $-0.0633^{* *}$ & $-0.0802 * *$ & $-0.0705^{* *}$ \\
\hline & $(0.029)$ & $(0.026)$ & $(0.033)$ & $(0.033)$ \\
\hline \multirow[t]{2}{*}{ Aggravated Assault } & -0.0221 & $-0.0292 * *$ & -0.0335 & -0.0396 \\
\hline & $(0.017)$ & $(0.013)$ & $(0.031)$ & $(0.026)$ \\
\hline Control Variables & No & Yes & No & Yes \\
\hline Year Fixed Effects & Yes & Yes & Yes & Yes \\
\hline State Fixed Effects & Yes & Yes & Yes & Yes \\
\hline Observations & 357 & 357 & 3,246 & 3,246 \\
\hline
\end{tabular}

Note: $* p<0.10, * * p<0.05, * * * p<0.01$. Estimates weighted by population. State sample includes all states and Washington, D.C. for the years 2010-2016. County sample includes contiguous-border counties for the years 2010-2014 and 2016. Standard errors reported in parentheses are clustered at the state-level. Each cell corresponds to a separate DID regression. 
Table 5: Medicaid Expansion Effect on State-Level Crime Rates: Robustness Checks

\begin{tabular}{|c|c|c|c|c|c|c|c|}
\hline \multirow{2}{*}{ DID Estimates } & $\begin{array}{l}\text { Main } \\
\text { Result }\end{array}$ & $\begin{array}{c}\text { Excluding } \\
\text { Prior Expansions }\end{array}$ & Border States & State Trend & Treatment Trend & $\begin{array}{l}\text { Excluding } \\
2014\end{array}$ & \multirow{2}{*}{$\begin{array}{c}\text { Permutation } \\
p \text {-values } \\
(7)\end{array}$} \\
\hline & $(1)$ & $(2)$ & $(3)$ & $(4)$ & $(5)$ & (6) & \\
\hline \multicolumn{8}{|c|}{ Dependent Variables: } \\
\hline \multicolumn{8}{|c|}{ Natural Log of Crime Rate per 100,000 residents } \\
\hline \multirow[t]{2}{*}{ Property Crime } & -0.0256 & $-0.0381 *$ & -0.00347 & $-0.0439 * *$ & $-0.0506^{* *}$ & -0.0152 & 0.2272 \\
\hline & $(0.021)$ & $(0.021)$ & $(0.021)$ & $(0.020)$ & $(0.021)$ & $(0.023)$ & \\
\hline \multirow[t]{2}{*}{ Burglary } & $-0.0375^{*}$ & $-0.0472 * *$ & -0.0394 & $-0.0658 * * *$ & $-0.0699 * * *$ & -0.0272 & 0.0963 \\
\hline & $(0.022)$ & $(0.023)$ & $(0.024)$ & $(0.022)$ & $(0.024)$ & $(0.029)$ & \\
\hline \multirow[t]{2}{*}{ Larceny Theft } & -0.0135 & -0.0261 & 0.0118 & -0.0299 & $-0.0376^{*}$ & -0.00249 & 0.5787 \\
\hline & $(0.019)$ & $(0.019)$ & $(0.019)$ & $(0.019)$ & $(0.019)$ & $(0.020)$ & \\
\hline \multirow[t]{2}{*}{ Motor Vehicle Theft } & $-0.104 * *$ & $-0.104 * *$ & $-0.0902 * *$ & $-0.0993 * * *$ & $-0.101 * *$ & $-0.108 *$ & 0.0132 \\
\hline & $(0.045)$ & $(0.045)$ & $(0.043)$ & $(0.036)$ & $(0.039)$ & $(0.059)$ & \\
\hline \multirow[t]{2}{*}{ Violent Crime } & $-0.0443 * * *$ & $-0.0363 * *$ & $-0.0322 * *$ & $-0.0452 * *$ & $-0.0584 * * *$ & -0.0243 & 0.0288 \\
\hline & $(0.014)$ & $(0.014)$ & $(0.012)$ & $(0.018)$ & $(0.015)$ & $(0.023)$ & \\
\hline \multirow[t]{2}{*}{ Criminal Homicide } & $-0.0813^{* *}$ & $-0.0632 *$ & $-0.0939 * *$ & $-0.0952 * * *$ & $-0.0849 * * *$ & -0.0596 & 0.0370 \\
\hline & $(0.032)$ & $(0.032)$ & $(0.040)$ & $(0.035)$ & $(0.031)$ & $(0.052)$ & \\
\hline \multirow[t]{2}{*}{ Robbery } & $-0.0633 * *$ & $-0.0526^{*}$ & $-0.0504^{*}$ & $-0.0907 * * *$ & $-0.0960 * * *$ & -0.0447 & 0.0234 \\
\hline & $(0.026)$ & $(0.028)$ & $(0.028)$ & $(0.022)$ & (0.019) & $(0.038)$ & \\
\hline \multirow[t]{2}{*}{ Aggravated Assault } & $-0.0292 * *$ & $-0.0233^{*}$ & $-0.0235^{*}$ & -0.0167 & $-0.0340 *$ & -0.00793 & 0.1497 \\
\hline & $(0.013)$ & $(0.014)$ & $(0.013)$ & $(0.020)$ & $(0.020)$ & $(0.021)$ & \\
\hline Observations & 357 & 301 & 273 & 357 & 357 & 306 & \\
\hline
\end{tabular}

Note: $* p<0.10$, ** $p<0.05$, *** $p<0.01$. Estimates weighted by population. Standard errors in parentheses are clustered at the state-level. Samples include all states and Washington, D.C. for the years 2010-2016, except for columns (2) and (6). In column (2), Maine, Tennessee, and Wisconsin are excluded from the control group, and Delaware, Washington, D.C., Massachusetts, New York, and Vermont are excluded from the treatment group. In column (6), year 2014 is excluded. Each cell corresponds to a separate DID regression that includes all control variables and state and year fixed effects. 
Table 6: Estimated Welfare Gains of Reduced Crime to Expansion States

\begin{tabular}{|c|c|c|c|c|}
\hline Crime Category & $\begin{array}{l}\text { Welfare Loss } \\
\text { Per Crime } \\
\text { (2019 Dollars) }\end{array}$ & $\begin{array}{l}\text { Total Crimes } \\
\text { in Expansion } \\
\text { States in } 2013\end{array}$ & $\begin{array}{c}\text { Estimated } \\
\text { Percentage } \\
\text { Crime Reduction }\end{array}$ & $\begin{array}{c}\text { Implied } \\
\text { Annual Welfare Gain } \\
\text { (Millions of } 2019 \text { Dollars) }\end{array}$ \\
\hline & [a] & {$[\mathrm{b}]$} & [c] & $=[\mathrm{a}] \times[\mathrm{b}] \times[\mathrm{c}]$ \\
\hline Aggravated Assault & 125,213 & 422,798 & $\begin{array}{c}2.92 \\
(0.37,5.47)\end{array}$ & $\begin{array}{c}\$ 1,546 \\
(\$ 197, \$ 2,895)\end{array}$ \\
\hline Burglary & 7,561 & $1,086,067$ & $\begin{array}{c}3.75 \\
(-0.56,8.06)\end{array}$ & $\begin{array}{c}\$ 308 \\
(\$-46, \$ 662)\end{array}$ \\
\hline Criminal Homicide & $10,510,001$ & 8,574 & $\begin{array}{c}8.13 \\
(1.86,14.40)\end{array}$ & $\begin{array}{c}\$ 7,326 \\
(\$ 1,674, \$ 12,978)\end{array}$ \\
\hline Motor Vehicle Theft & 12,603 & 452,691 & $\begin{array}{c}10.4 \\
(1.58,19.22)\end{array}$ & $\begin{array}{c}\$ 593 \\
(\$ 90, \$ 1,097)\end{array}$ \\
\hline Robbery & 49,503 & 227,797 & $\begin{array}{c}6.33 \\
(1.23,11.43)\end{array}$ & $\begin{array}{c}\$ 714 \\
(\$ 139, \$ 1,288)\end{array}$ \\
\hline Total & & & & $\begin{array}{c}\$ 10,487 \\
(\$ 2,054, \$ 18,920)\end{array}$ \\
\hline
\end{tabular}

Note: $95 \%$ confidence intervals given in parentheses (based on 1.96 critical value). Welfare loss per crime estimates taken from Table 5 of McCollister et al. (2010) and inflated by 17\% (per the CPI) to 2019 dollars. Crime reduction estimates and standard errors are taken from Table 4, column (2). 
Figure 1: Medicaid Expansion Effect on Aggregated Crime Categories:

State-Level Event Study Estimates
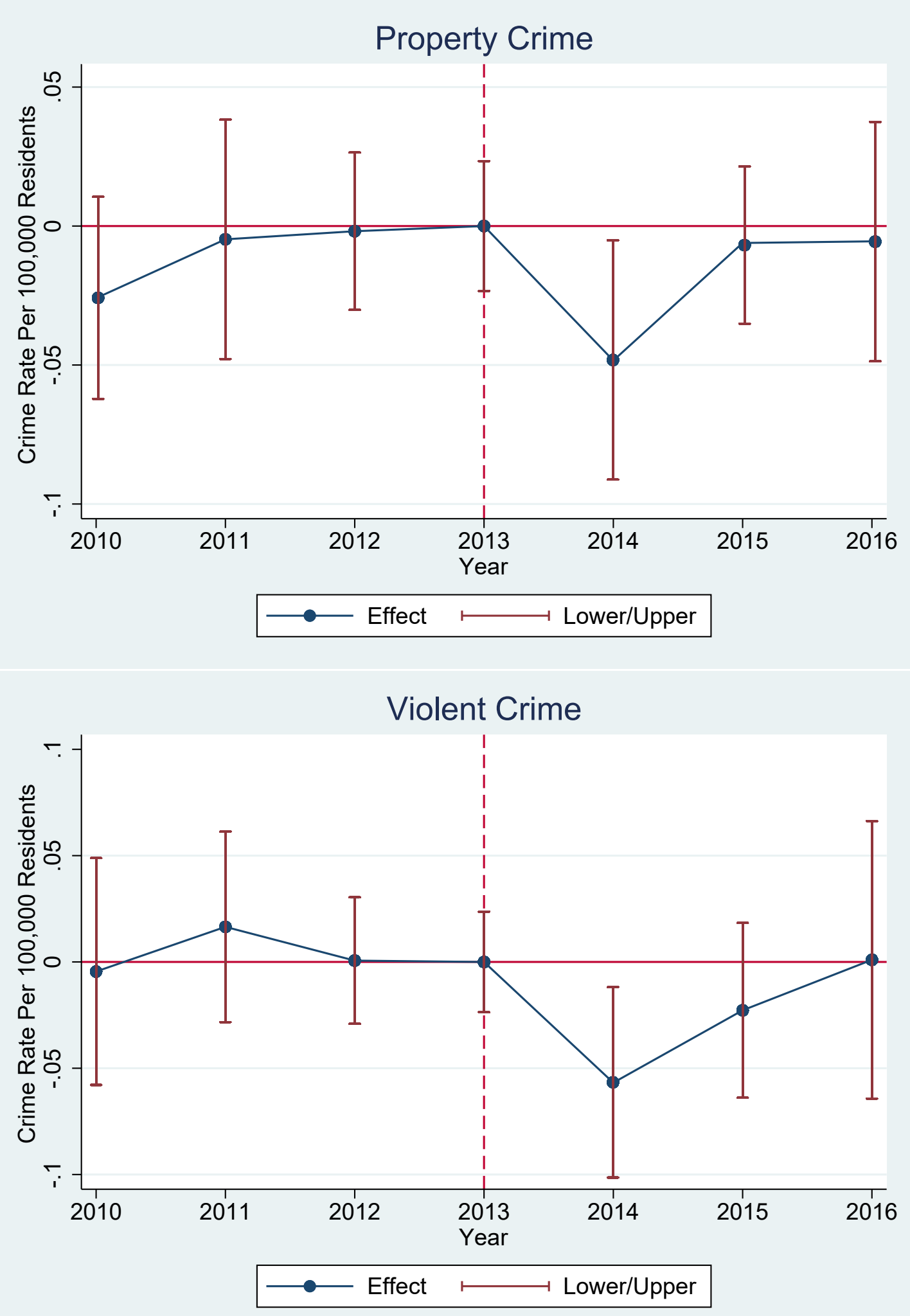
Figure 2: Medicaid Expansion Effect on Crime Sub-Categories: State-Level Event Study Estimates
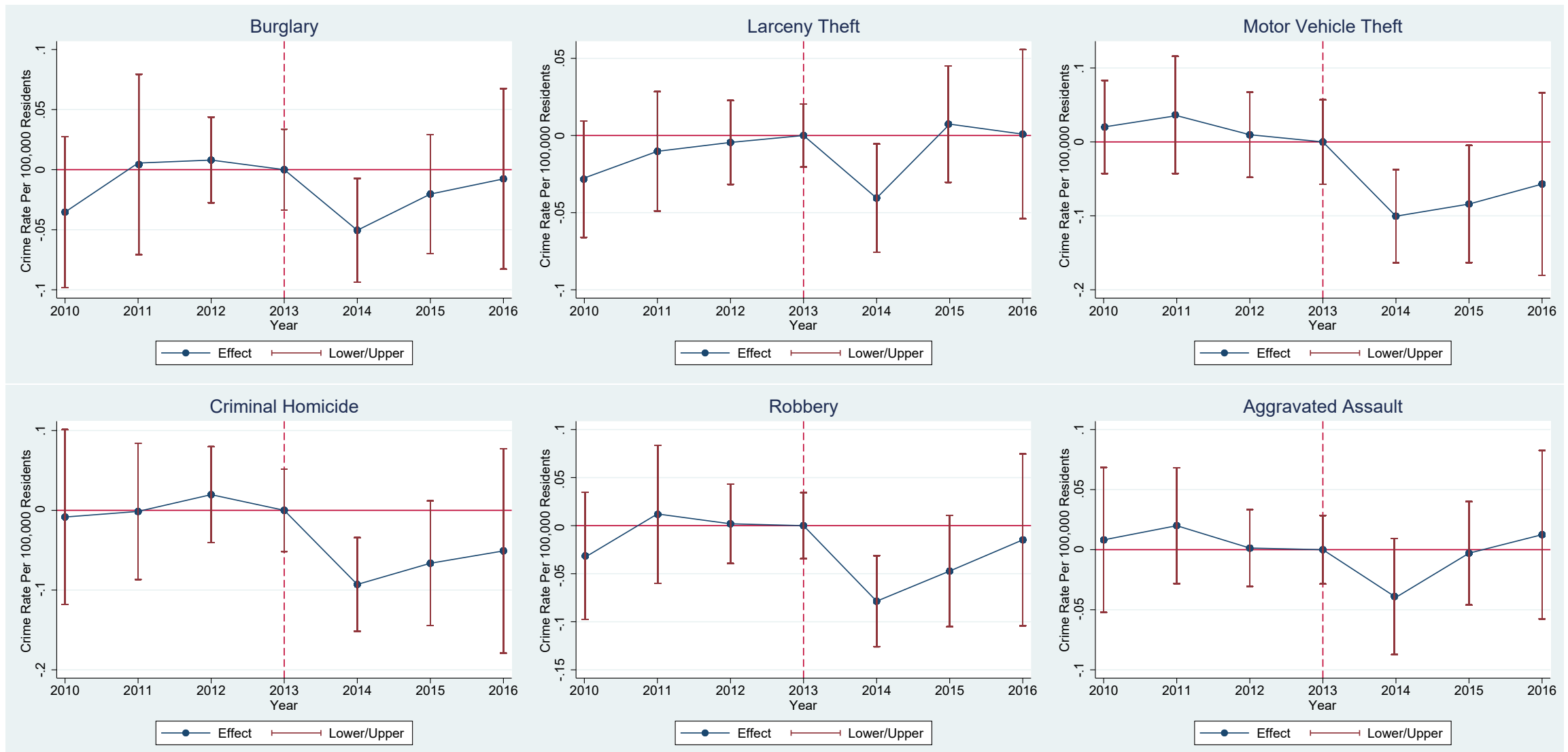
Figure 3: Medicaid Expansion Effect on Aggregated Crime Categories:

County-Level Event Study Estimates
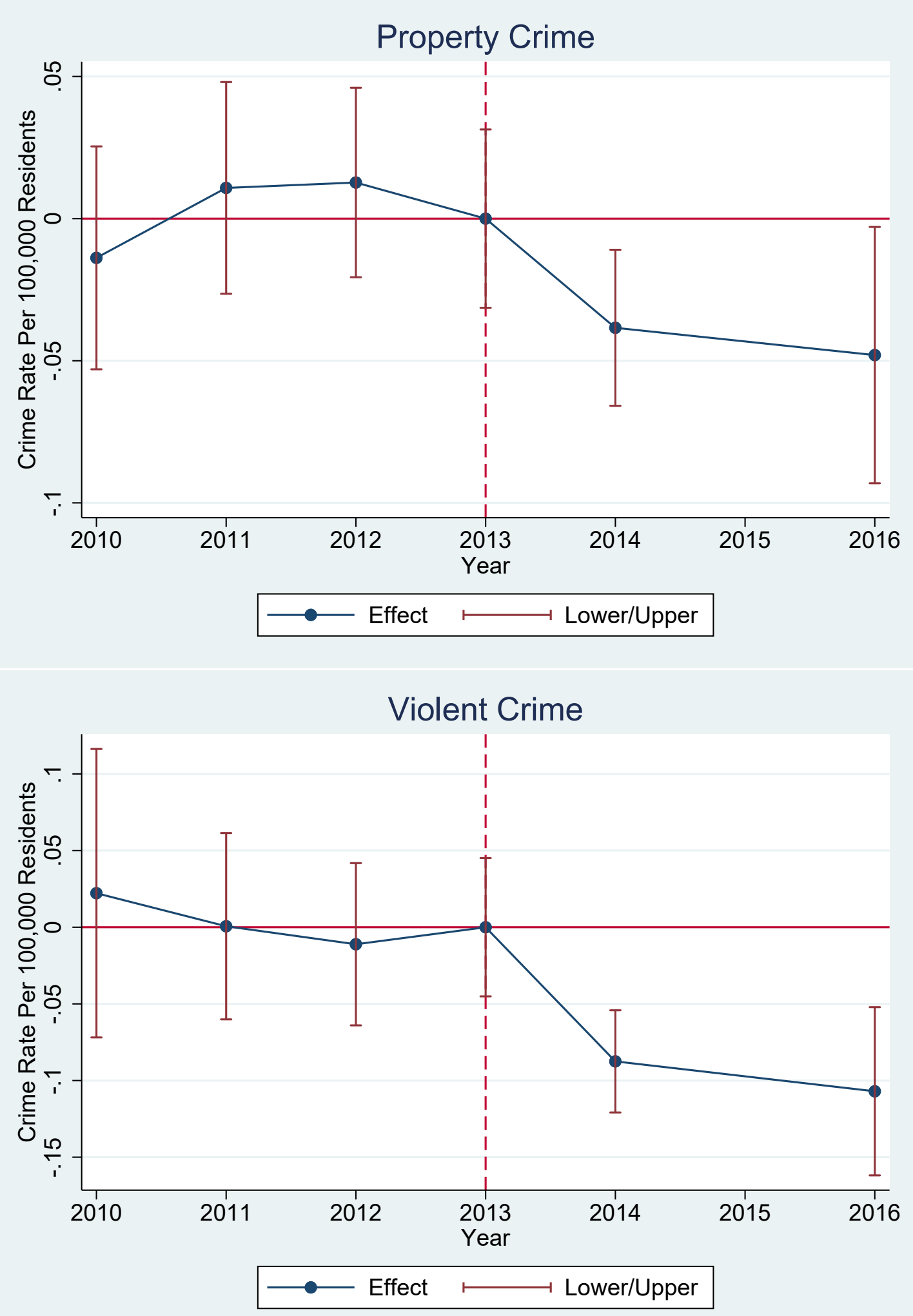
Figure 4: Medicaid Expansion Effect on Crime Sub-Categories: County-Level Event Study Estimates
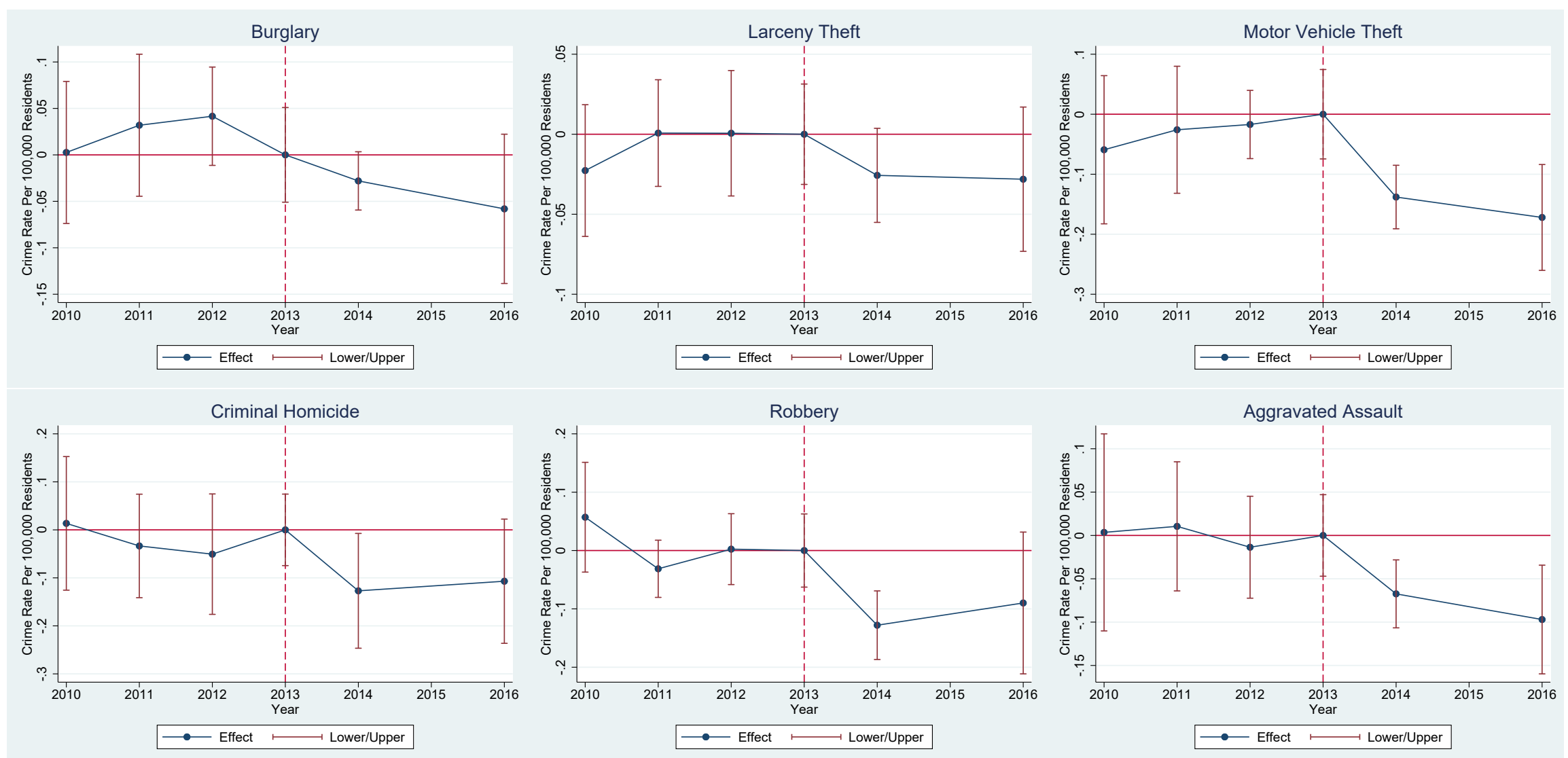


\section{Appendix}


Appendix Figure 1: Medicaid Expansion Effect on Aggregated Crime Categories: DID Method
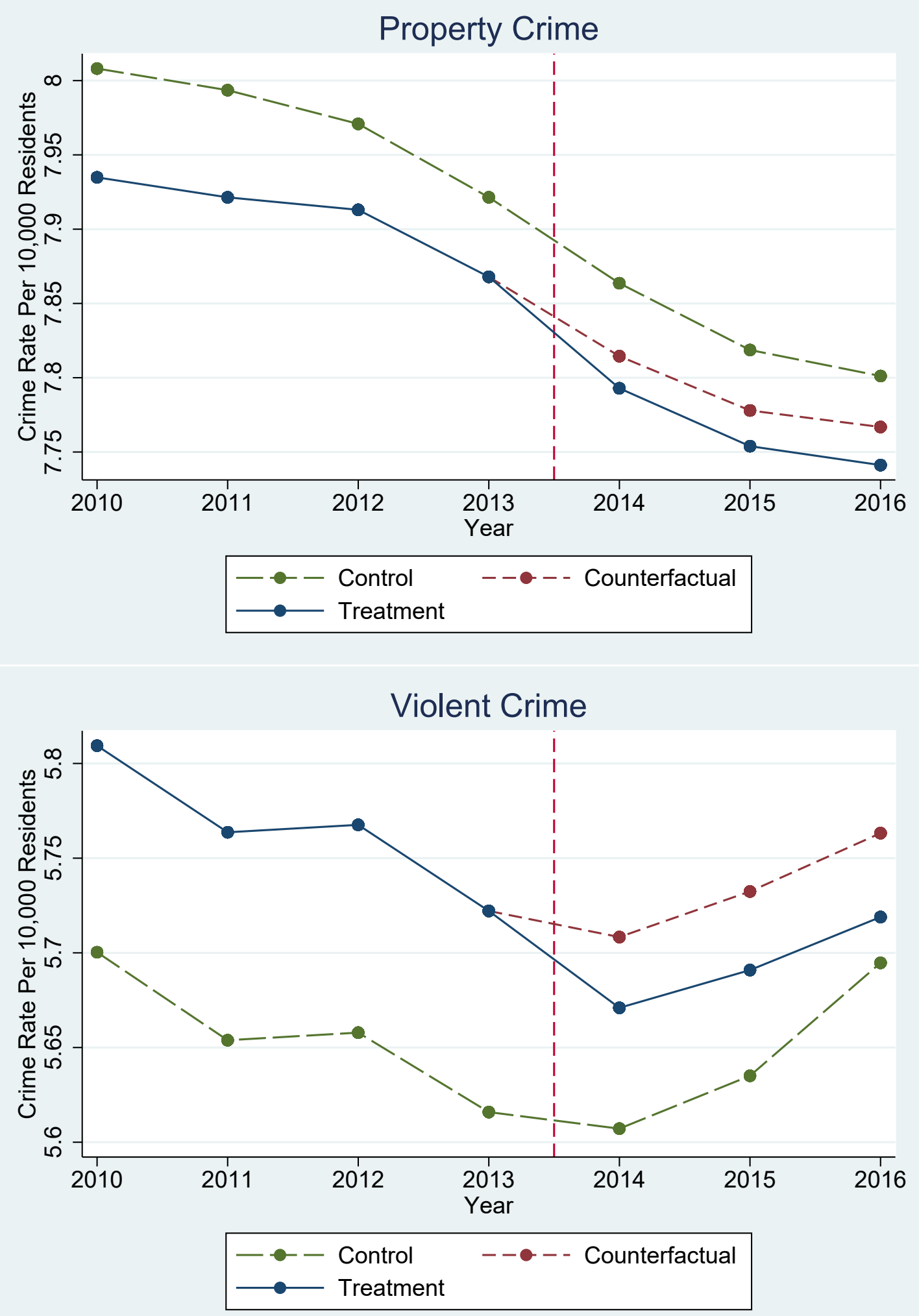
Appendix Figure 2: Medicaid Expansion Effect on Crime Sub-Categories: DID Method

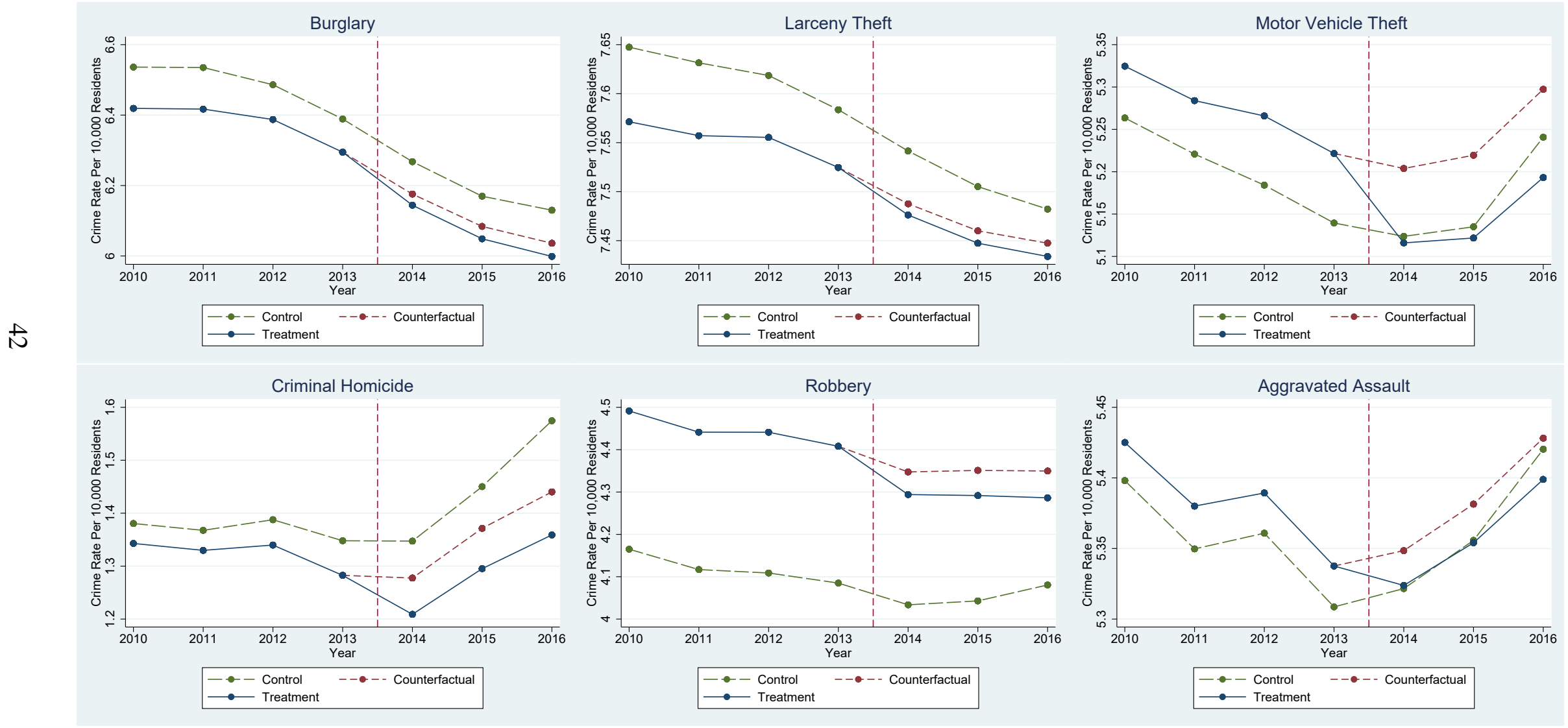


Appendix Table 1: Estimated Effect of the Medicaid Expansion On State-Level Crime Rates: Event Study Result

\begin{tabular}{|c|c|c|c|c|c|c|c|c|}
\hline \multirow{3}{*}{$\begin{array}{l}\text { Dependent variable: } \\
\text { Natural Log of Crime } \\
\text { Rate per } 100,000 \text { residents }\end{array}$} & \multicolumn{8}{|c|}{ All States Sample } \\
\hline & Property & Burglary & Larceny & Motor & Violent & Homicide & Robbery & Assault \\
\hline & (1) & (2) & (3) & (4) & (5) & (6) & (7) & (8) \\
\hline \multirow[t]{2}{*}{ 2010*Treatment } & -0.0278 & -0.0406 & -0.0333 & 0.0131 & -0.00486 & -0.00714 & -0.0367 & 0.00917 \\
\hline & $(0.019)$ & $(0.029)$ & $(0.028)$ & $(0.045)$ & $(0.024)$ & $(0.051)$ & $(0.031)$ & $(0.032)$ \\
\hline \multirow[t]{2}{*}{$2011 *$ Treatment } & -0.00532 & 0.00398 & -0.0109 & 0.0330 & 0.0160 & -0.00161 & 0.0102 & 0.0204 \\
\hline & $(0.024)$ & $(0.035)$ & $(0.031)$ & $(0.050)$ & $(0.021)$ & $(0.044)$ & $(0.034)$ & $(0.025)$ \\
\hline \multirow[t]{2}{*}{$2012 *$ Treatment } & -0.00206 & 0.00903 & -0.00410 & 0.00115 & 0.000105 & 0.0202 & 0.00222 & 0.00096 \\
\hline & $(0.013)$ & $(0.021)$ & $(0.018)$ & $(0.038)$ & $(0.013)$ & $(0.031)$ & $(0.021)$ & $(0.014)$ \\
\hline \multirow[t]{2}{*}{$2014 *$ Treatment } & $-0.0484^{*}$ & $-0.0509 *$ & -0.0416 & $-0.102 * *$ & $-0.0571 * *$ & $-0.0897 * * *$ & $-0.0786 * * *$ & -0.0400 \\
\hline & $(0.028)$ & $(0.023)$ & $(0.029)$ & $(0.044)$ & $(0.024)$ & $(0.034)$ & $(0.025)$ & $(0.026)$ \\
\hline \multirow[t]{2}{*}{$2015 *$ Treatment } & -0.00708 & -0.0205 & 0.00568 & $-0.0867 *$ & -0.0233 & -0.0690 & -0.0472 & -0.00290 \\
\hline & $(0.015)$ & $(0.024)$ & $(0.031)$ & $(0.051)$ & $(0.018)$ & $(0.045)$ & $(0.029)$ & $(0.019)$ \\
\hline \multirow[t]{2}{*}{$2016 *$ Treatment } & -0.00592 & -0.00933 & 0.000510 & -0.0607 & 0.00118 & -0.0518 & -0.0128 & 0.0113 \\
\hline & $(0.026)$ & $(0.038)$ & $(0.036)$ & $(0.068)$ & $(0.033)$ & $(0.076)$ & $(0.045)$ & $(0.036)$ \\
\hline$P$ value of Jointly Pre-treatment & 0.1889 & 0.1453 & 0.2163 & 0.8414 & 0.5339 & 0.8823 & 0.5538 & 0.7685 \\
\hline$P$ value of Jointly Post-treatment & 0.2422 & 0.1623 & 0.2384 & 0.0754 & 0.0113 & 0.0201 & 0.0040 & 0.3232 \\
\hline
\end{tabular}

Note: $* p<0.10, * * p<0.05, * * * p<0.01$; Standard errors in parentheses are clustered at the state-level. This sample includes all states and Washington D.C. for the year 2010-2016. Analytic weighted by population. Control variable, year fixed effect, state fixed effect are included in each regression. 
Appendix Table 2: Estimated Effect of the Medicaid Expansion on County-Level Crime Rates: Event Study Result

\begin{tabular}{|c|c|c|c|c|c|c|c|c|}
\hline \multirow{2}{*}{$\begin{array}{l}\text { Dependent variable: } \\
\text { Natural Log of Crime }\end{array}$} & \multicolumn{8}{|c|}{ Contiguous-Border Counties Sample } \\
\hline & Property & Burglary & Larceny & Motor & Violent & Homicide & Robbery & Assault \\
\hline Rate per 100,000 residents & (1) & (2) & (3) & (4) & $(5)$ & $(6)$ & (7) & $(8)$ \\
\hline \multirow[t]{2}{*}{$2010 *$ Treatment } & -0.0138 & 0.002603 & -0.0227 & -0.0592 & 0.0222 & 0.0135 & 0.0571 & 0.00354 \\
\hline & $(0.020)$ & $(0.039)$ & $(0.021)$ & $(0.063)$ & $(0.048)$ & $(0.071)$ & $(0.048)$ & $(0.058)$ \\
\hline \multirow[t]{2}{*}{$2011 *$ Treatment } & 0.0108 & 0.0319 & 0.000720 & -0.0259 & 0.000655 & -0.0335 & -0.0313 & 0.0105 \\
\hline & $(0.019)$ & $(0.039)$ & $(0.017)$ & $(0.054)$ & $(0.031)$ & $(0.055)$ & $(0.025)$ & $(0.038)$ \\
\hline \multirow[t]{2}{*}{$2012 *$ Treatment } & 0.0127 & 0.0416 & 0.000609 & -0.0171 & -0.0111 & -0.0506 & 0.00237 & -0.0136 \\
\hline & $(0.017)$ & $(0.027)$ & $(0.020)$ & $(0.029)$ & $(0.027)$ & $(0.064)$ & $(0.031)$ & $(0.030)$ \\
\hline \multirow[t]{2}{*}{$2014 *$ Treatment } & $-0.0384 * * *$ & $-0.0280 *$ & $-0.0257 *$ & $-0.138 * * *$ & $-0.0875^{* * *}$ & $-0.127 * *$ & $-0.128 * * *$ & $-0.0674 * * *$ \\
\hline & $(0.014)$ & $(0.016)$ & $(0.015)$ & $(0.027)$ & $(0.017)$ & $(0.061)$ & $(0.030)$ & $(0.020)$ \\
\hline \multirow[t]{2}{*}{$2016^{*}$ Treatment } & $-0.0480 * *$ & -0.0581 & -0.0281 & $-0.172 * * *$ & $-0.107 * * *$ & -0.107 & -0.0899 & $-0.0970 * * *$ \\
\hline & $(0.023)$ & $(0.041)$ & $(0.023)$ & $(0.045)$ & $(0.028)$ & $(0.066)$ & $(0.062)$ & $(0.032)$ \\
\hline$P$ value of Jointly Pre-treatment & 0.5038 & 0.3445 & 0.4729 & 0.7239 & 0.7885 & 0.8497 & 0.1158 & 0.8889 \\
\hline $\mathrm{P}$ value of Jointly Post-treatment & 0.0181 & 0.1422 & 0.2123 & 0.0000 & 0.0000 & 0.0927 & 0.0004 & 0.0017 \\
\hline
\end{tabular}

Note: $* p<0.10, * * p<0.05, * * * p<0.01$; Standard errors in parentheses are clustered at the state level. Sample includes contiguous-border counties for the years 2010-2014 and 2016. Weighted by population. Each column presents a separate regression result. Control variables and year and state fixed effects are included in each regression. 
Appendix Figure 3: Medicaid Expansion Effect After Dropping One State From Sample, by State

Property Crime

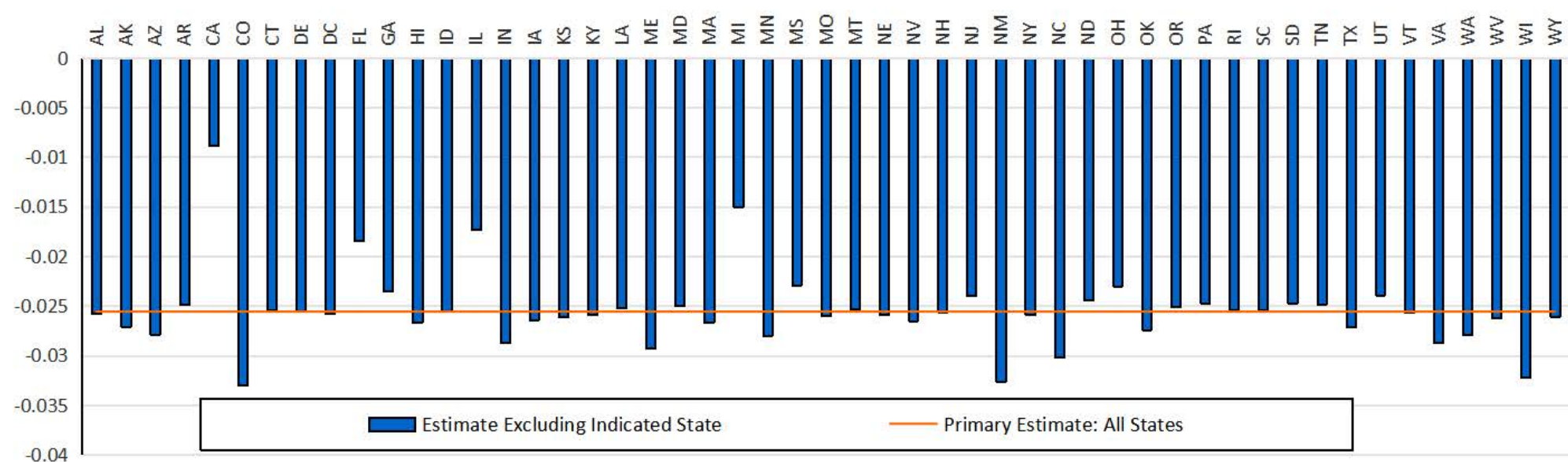

i

Violent Crime

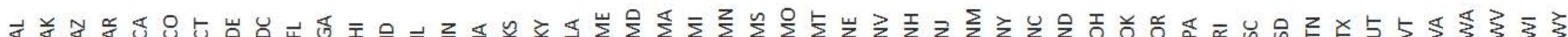

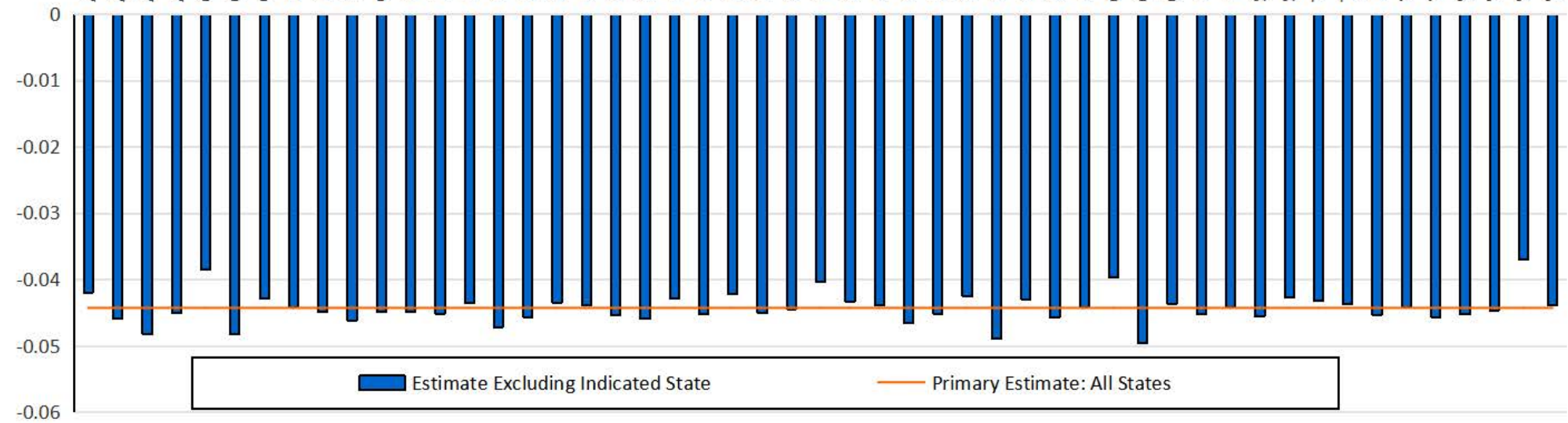

Note: All estimates produced by the same model and data as in Table 4, column (2) after excluding observations for the state indicated. Primary estimates are our main results without eliminating any states. 
Appendix Table 3: Replication of Vogler (2017)'s Main Result

\begin{tabular}{|c|c|c|}
\hline \multirow{2}{*}{ DID Estimates } & \multicolumn{2}{|c|}{ All States Sample } \\
\hline & (1) & (2) \\
\hline \multicolumn{3}{|l|}{ Dependent Variables: } \\
\hline \multicolumn{3}{|c|}{ Natural Log of Crime Rate per 100,000 residents } \\
\hline \multirow[t]{2}{*}{ Property Crime } & $-0.030 *$ & -0.0277 \\
\hline & $(0.018)$ & $(0.019)$ \\
\hline \multirow[t]{2}{*}{ Burglary } & $-0.043 * *$ & $-0.0536^{* *}$ \\
\hline & $(0.021)$ & $(0.023)$ \\
\hline \multirow[t]{2}{*}{ Larceny Theft } & -0.010 & -0.00986 \\
\hline & $(0.018)$ & $(0.018)$ \\
\hline \multirow[t]{2}{*}{ Motor Vehicle Theft } & $-0.115 * * *$ & $-0.114 * *$ \\
\hline & $(0.041)$ & $(0.044)$ \\
\hline \multirow[t]{2}{*}{ Violent Crime } & $-0.058 * * *$ & $-0.0603 * * *$ \\
\hline & $(0.018)$ & $(0.015)$ \\
\hline \multirow[t]{2}{*}{ Criminal Homicide } & $-0.116 * * *$ & $-0.106^{* * *}$ \\
\hline & $(0.039)$ & $(0.031)$ \\
\hline \multirow[t]{2}{*}{ Robbery } & $-0.082 * * *$ & $-0.0735 * * *$ \\
\hline & $(0.028)$ & $(0.026)$ \\
\hline \multirow[t]{2}{*}{ Aggravated Assault } & $-0.047 * * *$ & $-0.0476 * * *$ \\
\hline & $(0.018)$ & $(0.015)$ \\
\hline Police Variables & Yes & Yes \\
\hline Observations & 306 & 306 \\
\hline \multicolumn{3}{|c|}{$\begin{array}{l}\text { Note: } * p<0.10, * * p<0.05, * * * p<0.01 \text {. Estimates weighted by population. Column } \\
\text { (1) presents actual estimates from Vogler (2017). Column (2) reports estimates obtained } \\
\text { using our preferred specification with the addition of endogenous police expenditure con- } \\
\text { trols and the same sample period used by Vogler, } 2010 \text { to } 2015 \text {. Sample includes all states } \\
\text { and Washington, D.C.. Standard errors in parentheses are clustered at the state-level. Each } \\
\text { of the reported cells correspond to a separate DID regression. }\end{array}$} \\
\hline
\end{tabular}

